\title{
PRODUCTION OF NON-ESTER RENEWABLE DIESEL BY THE HYDROGENATION OF VEGETABLE OIL ON THE 15Co5Ni-10Ce / $\mathrm{Al}_{2} \mathrm{O}_{3}$ CATALYST
}

\author{
XI-GEN HUANG ${ }^{1,2}$, ZHI-PING LE ${ }^{1, *}$ AND LIN LI \\ ${ }^{1}$ Department of Chemistry, Nanchang University, Nanchang, 330031, P. R. China \\ ${ }^{2}$ Department of Chemistry, Jiangxi Agricultural University, Nanchang 330045, P. R. China
}

\begin{abstract}
The catalysts by incipient wetness impregnation method were prepared and characterized by XRD, BET, $\mathrm{H}_{2}-\mathrm{TPD}, \mathrm{NH}_{3}-\mathrm{TPD}$ and $\mathrm{H}_{2}-\mathrm{TPR}$ analysis, and the catalyst activity was detected by WFSM-3060 high-pressure reactor. Effective double metal catalysts were produced by using $\gamma$ - $\mathrm{Al}_{2} \mathrm{O}_{3}$ as carrier and Co and Ni as activity center, and more effectiveness by using Ce to modify. The results revealed that the $15 \mathrm{Co} 5 \mathrm{Ni}-10 \mathrm{Ce}$ catalyst was the best in producing bio-fuels. The catalyst had good thermal stability, three kinds of adsorbed sites and three kinds of acidic sites. Compared with sintering, the catalyst deactivation was due to coke deposition. The results of FT - IR, SF-3, GC and GC-MS indicated that reaction temperature is the key factor and that oil velocity is a very important factor. The optimized condition was at reaction temperature of $450^{\circ} \mathrm{C}$, reaction pressure of $3.0 \mathrm{MPa}$, oil velocity of $0.1 \mathrm{~mL} / \mathrm{min}$ and the gas velocity of $35 \mathrm{~mL} / \mathrm{min}$, respectively. The alkanes and alkenes content of liquid products are $50.02 \%$ and $40.03 \%$ under the optimized condition. The main products are the hydrocarbon compounds under $\mathrm{C}_{18}$. The results of $\mathrm{GC}$ online and trace water determination showed that the main products of oxygen in the oil are $\mathrm{CO}$ and $\mathrm{CO}_{2}$, and that the minor product is $\mathrm{H}_{2} \mathrm{O}$. The importance and the economical production of the Non-ester renewable diesel from vegetable oil are presented. From the results of FTIR, SF-3 and GC-MS, the generating mechanism of Non- ester renewable diesel was deduced.
\end{abstract}

Keywords: Bio-fuels, $15 \mathrm{Co} 5 \mathrm{Ni}-10 \mathrm{Ce} / \gamma-\mathrm{Al}_{2} \mathrm{O}_{3}$ catalyst, decarboxylation, deoxidization, hydrogenation.

\section{INTRODUCTION}

Coal and petroleum are the promising fossil fuels for energy supply in the future. But the quantity of petroleum and coal are becoming less, and the quality of the crude oil is becoming poorer and poorer every day. However, the demand of the crude oil has been on the increase by $26 \%$ every year since 1995 caused by the rapid growth of the world economy ${ }^{1-3}$, so the price of the crude

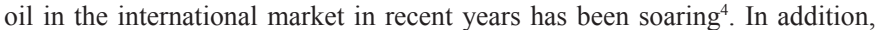
the environmental problems caused by the extensive use of fossil fuel have been more serious. Many countries are revising the strict emission standards and developing renewable energy sources (RES), the aim of which is to reduce the significant dependence on import energy and the crude oil. Biomass is the only renewable energy containing carbon and can be converted into liquid fuels and fine chemicals ${ }^{5-8}$. The conversion of biomass into bio-fuels is regarded as a carbon-cycling between the chemical conversion (Biomass $\rightarrow$ hydrocarbon $+\mathrm{CO}_{2}$ ) and the photosynthesis (light $+\mathrm{CO}_{2}+\mathrm{H}_{2} \mathrm{O} \rightarrow$ Biomass), so biofuels can be considered to be zero emission of $\mathrm{CO}_{2}$. Compared with fossil fuels, biomass contain less of sulfur and nitrogen, so the content of sulfur and nitrogen is less in bio-fuels, which leads to lower emissions of $\mathrm{SO}_{2}$ and $\mathrm{NOx}^{9-}$ ${ }^{11}$. The potential and importance of RES was evaluated and examined from the economic and environmental viewpoints in Slovenian ${ }^{5}$. By 2020, the E.U. has adopted a target that the $10 \%$ energy of the transportation energy is used by the conversion of different triglycerides to different bio-fuels ${ }^{6}$. The use of RES is considered to be a solution to the problems of energy shortage and the pollution in the long-term.

Nowadays fatty acid methyl esters (FAME), called as first generation bio-diesel, could be produced from a variety of biomass feed-stock using suitable conversion technique, especially use the nonfood plant that is rich in triglycerides or sugars ${ }^{12-15}$. Bio-diesel production can also be carried out by homogeneous alkali, acid and enzyme ${ }^{16-25}$. The use of FAME plays a positive and important role in solving the problems of energy shortage and the pollution in a period of time. Compared with petroleum-derived fuels, FAME has many physical-chemical disadvantages (e.g. the higher cloud point, the higher viscosity, the freezing point, the pour point, the poor oxidation stability etc. ${ }^{26}$. To overcome these disadvantages and to reach better quality fuel, the most viable way is the deoxidization of triglyceride to Non-ester renewable diesel (NERD), which is called second generation bio-fuels. Snåre M. et al. ${ }^{27}$, Kubičková I. et al. ${ }^{28}$, Katikaneni S. P. R. et al. ${ }^{29}$ and Vonghia E. et al. ${ }^{30}$ are earlier concerned about the research of the deoxidization of triglyceride to NERD. The deoxidization of fatty acids and their methyl esters has been studied extensively on the $\mathrm{Pd} / \mathrm{C}^{31}, \mathrm{Pd} / \mathrm{SBA}-15^{32}$ and $\mathrm{Pt} / \gamma-\mathrm{Al}_{2} \mathrm{O}_{3}{ }^{33}$ noble metal catalysts. Moreover, the deoxidization of triglycerides can be achieved on these catalysts such as sulfided $\mathrm{CoMo}, \mathrm{NiMo}, \mathrm{NiW}$ supported on $\gamma-\mathrm{Al}_{2} \mathrm{O}_{3}{ }^{34}$ and $\mathrm{Ni}-$
$\mathrm{Mo} / \gamma-\mathrm{Al}_{2} \mathrm{O}_{3} / \mathrm{F}^{35}$ Catalysts.

$\mathrm{Co} / \gamma-\mathrm{Al}_{2} \mathrm{O}_{3}$ is an effective catalyst in Fischer -Tropsch synthesis ${ }^{36}$, and the $\mathrm{Ni} / \gamma-\mathrm{Al}_{2}^{2} \mathrm{O}_{3}$ is a good catalyst in the hydrogenation activity ${ }^{34}$. In the paper, economical and non-sulfide transition metal catalysts were produced by using $\gamma-\mathrm{Al}_{2} \mathrm{O}_{3}$ as carrier and $\mathrm{Co}$ and $\mathrm{Ni}$ as activity center, and more effectiveness by using Ce to modify, and the non-ester renewable diesel by the hydrogenation of vegetable oil on the $15 \mathrm{Co} 5 \mathrm{Ni}-10 \mathrm{Ce} / \mathrm{Al}_{2} \mathrm{O}_{3}$ catalyst was produced. The standards of bio-fuels had been further improved because of low oxygen content and high content of the alkanes and alkenes in the bio-fuels. The research result of continuous conversion of vegetable oil to bio-fuels provided a scientific basis for solving the problem of energy shortage.

\section{EXPERIMENTAL}

\subsection{Experimental materials and setup}

Rapeseed oil (industrial grade) with the following mass distribution of fatty acids (purchased from FuLinMen Co. 1td, Beijing, China) was used as a starting material: palmitic acid: $5.4 \%$, stearic acid: $1.87 \%$, oleic acid: 46.04\%, linoleic acid: $20.36 \%$, linolenic acid $: 7.98 \%$, eicosanoic acid: $0.63 \%$, eicosenoic acid: $1.75 \%$, erucic acid $: 15.75 \%$.

The experiment of the conversion of vegetable oil to bio-fuels was carried out by WFSM-3060 high-pressure reactor. The velocity of $\mathrm{H}_{2}$ and the crude oil were controlled by a mass flow-meter. These two streams were mixed in the reactor. All kinds of factors were respectively investigated from reaction temperature, reaction pressure, the oil speed and the velocity of $\mathrm{H}_{2}$. The support $\left(\gamma-\mathrm{A}_{2} \mathrm{O}_{3}\right)$ was crushed and sieved to $0.2-0.35 \mathrm{~mm}$ particle size fraction. The mass of the catalyst is $1.0 \mathrm{~g}$ and the catalyst-bed length is about $0.95-1.0 \mathrm{~cm}$.

All kinds of catalysts by incipient wetness impregnation method were prepared. After impregnation, the solution were stirred and placed at room temperature for $24 \mathrm{~h}$, and dried in an oven at $120^{\circ} \mathrm{C}$ overnight and calcined at $500^{\circ} \mathrm{C}$ for $5 \mathrm{~h}$ in the muffle furnace at a rate of $10^{\circ} \mathrm{C} / \mathrm{min}$.

During the experimental work, the total loading of $\mathrm{NiO}$ and $\mathrm{CoO}$ was immobility about $20 \%$, and the loading of $\mathrm{NiO}$ and $\mathrm{CoO}$ of $\mathrm{Co}-\mathrm{Ni}$ bimetallic catalyst was immobility about $5 \%$ and $15 \% . \mathrm{K}^{+}$and Ce were added to the catalysts for reducing the carbon deposition and improving the activity of the catalysts. All sorts of the catalysts were marked in order as $20 \mathrm{Ni}, 20 \mathrm{Co}$, $15 \mathrm{Co} 5 \mathrm{Ni}, 15 \mathrm{Co} 5 \mathrm{Ni}-5 \mathrm{Ce}$ and $15 \mathrm{Co} 5 \mathrm{Ni}-10 \mathrm{Ce}$, respectively.

\subsection{Catalyst characterization}

The textural characteristics of the support and the catalysts were analyzed by $\mathrm{N}_{2}$ physisorption method. $\mathrm{N}_{2}$ adsorption and desorption isotherms were performed at $77 \mathrm{~K}$ on MicromeriticsASAP2020C equipment. The samples were outgassed in vacuum $(\approx 1 \mu \mathrm{m} \mathrm{Hg})$ at $573 \mathrm{~K}$ for $3 \mathrm{~h}$ before the measurement. The pore diameter and pore volume were calculated from the analysis of desorption 
branch of the isotherm by the Barrett-Joyner-Halenda (BJH) method. X-ray diffraction (XRD) measurements were performed on the catalysts using the monochromic $\mathrm{Cu} \mathrm{K \alpha}$ radiation of a Bruker AXS D8 Focus diffractometer instrument at $40 \mathrm{kV}$ and $30 \mathrm{~mA}$. The XRD patterns were recorded for $2 \theta$ $=10 \sim 80$ degrees with a step width of 0.01 degree at a rate of $1.25^{\circ} / \mathrm{min}$. Temperature programmed reduction (TPR) measurements were performed with a Chemisorb2750 instrument. The catalyst samples were purged with argon at $150^{\circ} \mathrm{C}$ for $30 \mathrm{~min}$ and cooled to $30^{\circ} \mathrm{C}$, then heated to $840^{\circ} \mathrm{C}$ at a rate of $10^{\circ} \mathrm{C} \mathrm{min}^{-1}$ and the $5 \mathrm{vol} \% \mathrm{H}_{2} / \mathrm{Ar}$ flowing rate with $30 \mathrm{~cm}^{3} \cdot \mathrm{min}^{-1}$. The consumption of hydrogen was monitored by a thermal conductivity detector (TCD). Temperature programmed desorption (TPD) measurements were performed with a Chemisorb2920 instrument. The catalysts were purged with argon at $150^{\circ} \mathrm{C}$ for $30 \mathrm{~min}$ and cooled to $50^{\circ} \mathrm{C}$ before the measurement of $\mathrm{H}_{2}$ or $\mathrm{NH}_{3}$ adsorption. When the base line is stable, the samples were heated to $800^{\circ} \mathrm{C}$ at a rate of $10^{\circ} \mathrm{C} \cdot \mathrm{min}^{-1}$. The signal of $\mathrm{H}_{2}$ or $\mathrm{NH}_{3}$ was monitored by a thermal conductivity detector. Deposited coke was measured by temperature programmed combustion by TGA/SDTA851 device.

1.3 Gas products analysis

The gas products were analyzed by GC online. GC equipped with a thermal conductivity detector and carbon molecular sieve column TDX$01(2.0 \mathrm{~m}, 2.0 \mathrm{~mm})$ were used to analyze the contents of $\mathrm{CO}$ and $\mathrm{CO}_{2}$ at a constant temperature of column $190^{\circ} \mathrm{C}$, current $110 \mathrm{~mA}$ and detector $160^{\circ} \mathrm{C}$, respectively. Reaction gas are collected and analyzed by GC online every 10 minute in order.

1.4 Liquid products analysis of FT-IR

The FT-IR spectra of the liquid product samples were recorded by a Nicolet 570027 Infrared Spectrophotometer in $4000-400 \mathrm{~cm}^{-1}$ with $\mathrm{KBr}$ pellet sample.

1.5 Liquid products analysis of GC-MS

GC-MS analysis using an Agilent 7890A GC (HP-5 column, $30 \mathrm{~m} \times 0.25$ $\mathrm{mm} \times 0.25 \mu \mathrm{m}$ ) coupled to an Agilent 5975C Inert MSD with a quadruplicate axis detector. Liquid product was dried for decrease water with dried $\mathrm{Na}_{2} \mathrm{SO}_{4}$. Liquid product was diluted 1:1 in cyclohexane and the diluted samples were injected onto a HP-5 column. Helium was used as the carrier gas at velocity rate of $54 \mathrm{~mL} / \mathrm{min}$ and that the split ratio was $50: 1$. The mass range from $\mathrm{m} / \mathrm{z}$ 50 - 550 was scanned with a speed of $0.3 \mathrm{~s}$ decade. Product identification was validated with a gas chromatograph-mass spectrometer.

1.6 The determination of trace water in the liquid products

Karl-Fisher coulometric titration method has been adopted to trace water content measurement of different substances. SF-3 (made in Zibo Instrument Co., Itd, China) trace water content meter has successfully adopted this method. The yield was calculated by the following equation ${ }^{3}$ :

Liquid product yield $\%=\frac{\text { Weight of Liquid bio }- \text { fuels }}{\text { Weight of the crude oil }} \times 100 \%$

$\mathrm{H}_{2} \mathrm{O}$ yield $\%=\frac{\text { Weight of } \mathrm{H}_{2} \mathrm{O}}{\text { Weight of the crude oil }} \times 100 \%$

Coke yield $\%=\frac{\text { Weight of coke }}{\text { Weight of the crude oil }} \times 100 \%$

Gas product yield $\%=1$ - Liquid product yield $\%-\mathrm{H}_{2} \mathrm{O}$ yield $\%$ - Coke yield $\%$

\section{RESULT AND DISCUSSION}

\subsection{XRD}

The XRD results were shown in Figure 1. As can be seen, the peaks of $\gamma-\mathrm{Al}_{2} \mathrm{O}_{3}$ exhibited at $17.0^{\circ}, 25.45^{\circ}, 37.0^{\circ}, 43.39^{\circ}$ and $67.0^{\circ}$, and the peaks of $\mathrm{NiAl} O$ O exhibited at $44.0^{\circ}$ and $62.0^{\circ}$ in the Ni20 catalyst. Compared with the peaks of $\gamma-\mathrm{Al}_{2} \mathrm{O}_{3}$, there were no obvious peaks of nickel oxide, which indicated that the phases highly dispersed in the support. As the content of cobalt or the total content of cobalt and nickel increased, new peaks at $44.9^{\circ}, 57.57^{\circ}$ and $67.0^{\circ}$ appeared for the catalysts of $20 \mathrm{Ni}, 15 \mathrm{Co} 5 \mathrm{Ni}, 15 \mathrm{Co} 5 \mathrm{Ni}-5 \mathrm{Ce}, 15 \mathrm{Co} 5 \mathrm{Ni}-$ $10 \mathrm{Ce}$ and $20 \mathrm{Co}$, which indicated that the mixed phase of $\mathrm{NiAl}_{2} \mathrm{O}_{4}$ and $\mathrm{CoAl}_{2} \mathrm{O}_{4}$ can be formed. It is not surprise to know that the bimetallic ${ }^{\mathrm{CO}}-\mathrm{Ni} / \gamma-\mathrm{Al}_{2} \mathrm{O}_{3}$ catalysts are better than the $\mathrm{Ni}$ or Co catalyst alone in the activity of the decarboxylation and the decarbonylation of triglyceride to bio-fuels.

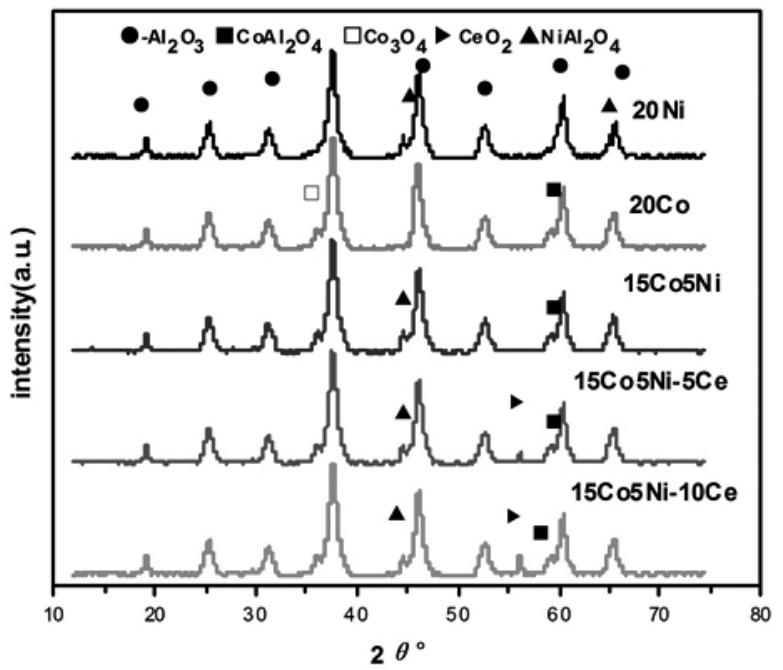

Fig. 1 XRD patterns of all kinds of the Catalysts

\subsection{BET}

The BET results of $15 \mathrm{Co} 5 \mathrm{Ni}-10 \mathrm{Ce}$ catalyst were analyzed and showed in the table 1 and Figure 2 on the fresh and the used catalysts. It can be seen from table1 that the surface areas and the pore volume of the catalyst show no significant difference before and after reaction, and the surface areas decreased from $166.4865 \mathrm{~m}^{2} \cdot \mathrm{g}^{-1}$ to $143.65 \mathrm{~m}^{2} \cdot \mathrm{g}^{-1}$, and the pore volume were obtained from $0.3226 \mathrm{~cm}^{3} \cdot \mathrm{g}^{-1}$ to $0.2878 \mathrm{~cm}^{3} \cdot \mathrm{g}^{-1}$. The $15 \mathrm{Co} 5 \mathrm{Ni}-10 \mathrm{Ce} / \gamma-\mathrm{Al}_{2} \mathrm{O}_{3}$ catalyst of the fresh and multiple used could keep structure stability in this reaction. Compared with sintering, the catalyst deactivation was due to coke deposition. Therefore, the capability of $15 \mathrm{Co} 5 \mathrm{Ni}-10 \mathrm{Ce}$ catalysts is very stable.

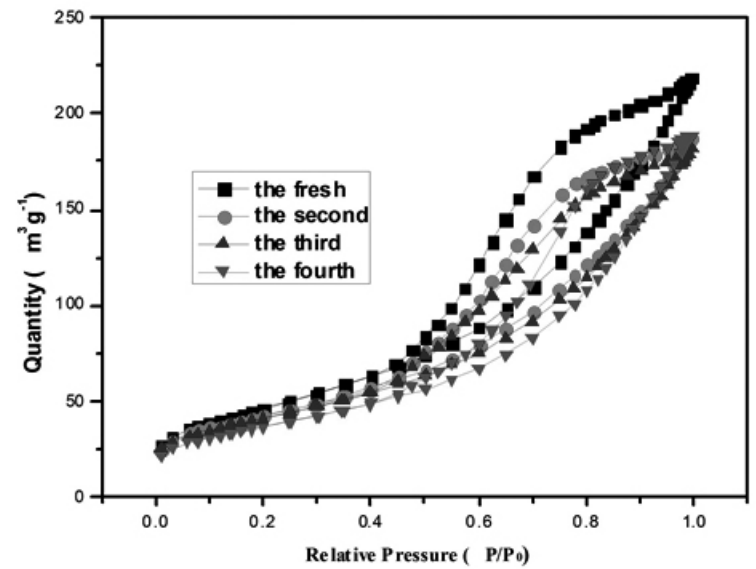

Fig. 2 BET patterns of the fresh and used catalysts.

\subsection{TPR}

The TPR result can be found from Figure 3 that the reduction peak of $358{ }^{\circ} \mathrm{C}$ in the $20 \mathrm{Ni}$ catalyst is attributed to the reduction of $\mathrm{Ni}^{2+}$ in the $\mathrm{NiO}$ phase, and the second peak of $437^{\circ} \mathrm{C}$ is associated with the reduction of $\mathrm{Ni}^{2+}$ in $\mathrm{NiAl}_{2} \mathrm{O}_{4}$. For the $20 \mathrm{Co}$ catalyst, the only reduction temperature of $370^{\circ} \mathrm{C}$ is likely attributed to the reduction of $\mathrm{Co}^{2+}$ in the $\mathrm{Co}_{3} \mathrm{O}_{4}$ phase. Moreover, the bimetallic $15 \mathrm{Co} 5 \mathrm{Ni}$ catalyst has two reduction peaks at about $420^{\circ} \mathrm{C}$ and $650^{\circ} \mathrm{C}$, and the peak of $420^{\circ} \mathrm{C}$ is associated with the reduction of $\mathrm{Ni}^{2+}$ in $\mathrm{NiAl}_{2} \mathrm{O}_{4}$, and that the peak of $650^{\circ} \mathrm{C}$ is associated with the reduction of $\mathrm{Co}^{2+}$ in $\mathrm{CoAl}_{2} \mathrm{O}_{4}$ species. What' more, the $15 \mathrm{Co} 5 \mathrm{Ni}-5 \mathrm{Ce}$ catalyst has two reduction peaks at $360^{\circ} \mathrm{C}$ and $485^{\circ} \mathrm{C}$, and the $15 \mathrm{Co} 5 \mathrm{Ni}-10 \mathrm{Ce}$ catalyst have two reduction peaks $360^{\circ} \mathrm{C}$ and $525^{\circ} \mathrm{C}$. The peak height of the reduction peak changed little, but the reduction peak temperature is shifted to lower temperature, which implies that the synergic effect was produced in the process of the preparation among cerium nitrate, nickel nitrate and cobalt nitrate species. The results revealed that the adding of cerium plays an important role in the reduced process. 
Table 1 BET parameter of the fresh and used catalysts.

\begin{tabular}{|c|c|c|c|c|}
\hline & $\begin{array}{c}\text { the } \\
\text { fresh }\end{array}$ & $\begin{array}{c}\text { the } \\
\text { second }\end{array}$ & $\begin{array}{c}\text { the } \\
\text { third }\end{array}$ & $\begin{array}{c}\text { the } \\
\text { fourth }\end{array}$ \\
\hline BET Surface Area $\left(\mathrm{m}^{2} / \mathrm{g}\right)$ & 166.487 & 154.164 & 151.25 & 143.65 \\
\hline $\begin{array}{c}\text { Single point adsorption } \\
\text { total pore volume of } \\
\left.\text { pores(cm } \mathrm{cm}^{3} / \mathrm{g}\right)\end{array}$ & 0.3226 & 0.2768 & 0.2697 & 0.2878 \\
\hline $\begin{array}{c}\text { BJH Adsorption cumulative } \\
\text { volume of pores }\left(\mathrm{cm}^{3} / \mathrm{g}\right)\end{array}$ & 0.3452 & 0.2969 & 0.2918 & 0.2979 \\
\hline $\begin{array}{c}\text { BJH Desorption cumulative } \\
\text { volume of pores(cm } 3 / \mathrm{g})\end{array}$ & 0.3426 & 0.2941 & 0.2912 & 0.2957 \\
\hline $\begin{array}{c}\text { Adsorption average pore } \\
\text { width(nm) }\end{array}$ & 7.7507 & 7.3654 & 7.3207 & 8.1434 \\
\hline $\begin{array}{c}\text { BJH Adsorption average } \\
\text { pore diameter(nm) }\end{array}$ & 6.9188 & 6.8437 & 6.8335 & 7.5806 \\
\hline $\begin{array}{c}\text { BJH Desorption average } \\
\text { pore diameter(nm) }\end{array}$ & 5.4113 & 5.4353 & 5.6897 & 6.0355 \\
\hline
\end{tabular}

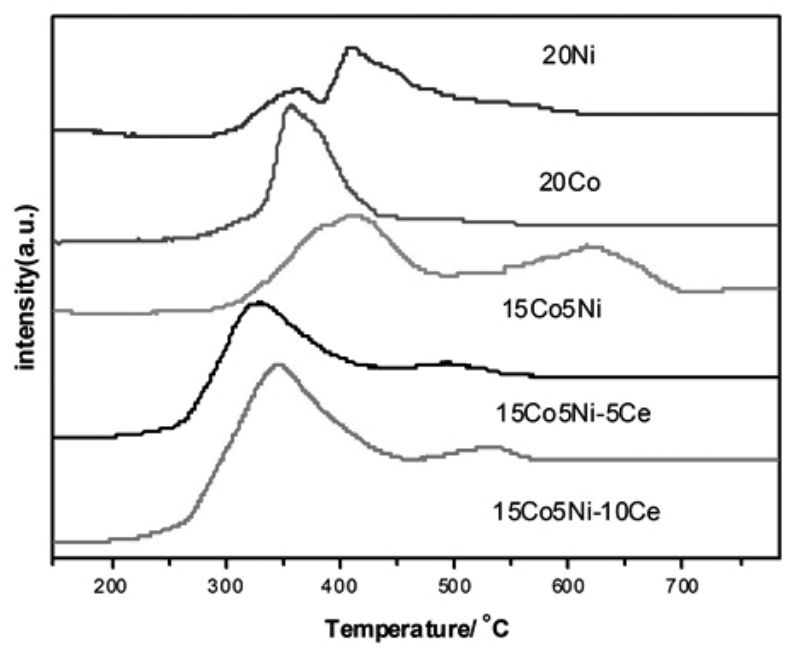

Fig. 3 TPR patterns of the different catalysts

$2.4 \mathrm{NH}_{3}-\mathrm{TPD}$

The acidic sites of the catalysts were measured by $\mathrm{NH}_{3}$-TPD. For all catalysts, an intense desorption peak was observed at $120^{\circ} \mathrm{C}$ in Figure 4, which can be attributed to weakly absorbed $\mathrm{NH}_{3}$. One peak of moderate acidity sites can be seen at around $220^{\circ} \mathrm{C}$ in all kinds of catalysts. Moreover, the $\mathrm{NH}_{3}$ TPD profile in Fig. 4 showed that three peaks at $220^{\circ} \mathrm{C}, 300^{\circ} \mathrm{C}$ and $420^{\circ} \mathrm{C}$ can be seen in the $20 \mathrm{Co}$ and $15 \mathrm{Co} 5 \mathrm{Ni}$ catalysts, which indicated that $20 \mathrm{Co}$ and $15 \mathrm{Co} 5 \mathrm{Ni}$ had two kinds of moderate acid sites and one strong acid site on their surface. What' more, one peak of strong acid site appeared at $550^{\circ} \mathrm{C}$ in the $15 \mathrm{Co} 5 \mathrm{Ni}, 15 \mathrm{Co} 5 \mathrm{Ni}-5 \mathrm{Ce}$ and $15 \mathrm{Co} 5 \mathrm{Ni}-10 \mathrm{Ce}$ catalysts, which indicated that the surfaces of the $15 \mathrm{Co} 5 \mathrm{Ni}, 15 \mathrm{Co} 5 \mathrm{Ni}-5 \mathrm{Ce}$ and $15 \mathrm{Co} 5 \mathrm{Ni}-10 \mathrm{Ce}$ catalysts had three kinds of acidity sites on theirs surface: weak acid, moderate acid and strong acid. With the introduction of Ce into the $15 \mathrm{Co} 5 \mathrm{Ni}$ framework, the $\mathrm{NH}_{3}$ adsorption peak at $300^{\circ} \mathrm{C}$ and $550^{\circ} \mathrm{C}$ increased significantly in the $15 \mathrm{Co} 5 \mathrm{Ni}^{3}-$ $5 \mathrm{Ce}$ and $15 \mathrm{Co} 5 \mathrm{Ni}-10 \mathrm{Ce}$ catalysts, which induced the formation of a large amount of Lewis on the theirs surface. The strong acid site is beneficial to the catalyst activity of the hydrogenation reaction and the deoxidization reaction ${ }^{32}$.

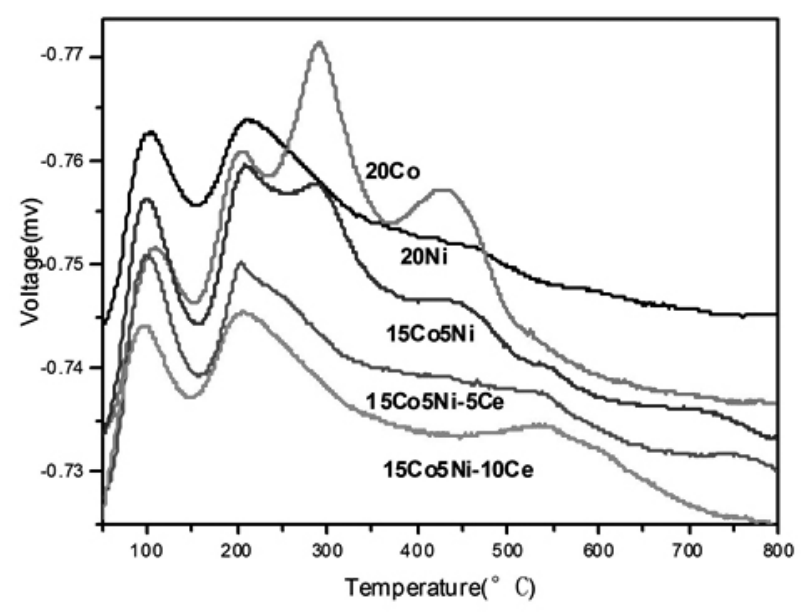

Fig. $4 \mathrm{NH}_{3}$-TPD patterns of the different catalysts

\section{$2.5 \mathrm{H}_{2}$-TPD}

The results of $\mathrm{H}_{2}$-TPD were given in Figure 5. The $\mathrm{H}_{2}$-TPD profile in Figure 5 showed that two similar intense desorption peaks of hydrogen at $120^{\circ} \mathrm{C}$ and $220^{\circ} \mathrm{C}$ in all kinds of catalysts. Moreover, there was a different hydrogen desorption curve over $400^{\circ} \mathrm{C}$ for $20 \mathrm{Co}$ catalysts, and the shoulder desorption peaks were centered at $450^{\circ} \mathrm{C}$ for the $20 \mathrm{Ni}$ and $15 \mathrm{Co} 5 \mathrm{Ni}$ catalysts. What' more, the $\mathrm{H}_{2}$-TPD profile in Figure 5 shows that one peak at $550^{\circ} \mathrm{C}$ can be seen in the $15 \mathrm{Co} 5 \mathrm{Ni}-5 \mathrm{Ce}$ and $15 \mathrm{Co} 5 \mathrm{Ni}-10 \mathrm{Ce}$ catalysts, which indicates that the $15 \mathrm{Co} 5 \mathrm{Ni}-5 \mathrm{Ce}$ and $15 \mathrm{Co} 5 \mathrm{Ni}-10 \mathrm{Ce}$ catalysts have three adsorbed sites. The higher desorption temperature makes desorption of reaction $\mathrm{H}_{2}$ harder, which is beneficial to the hydrogenation reaction ${ }^{3}$. The strong adsorbed site is beneficial to the catalyst activity of the hydrogenation reaction, which implied that the adding of cerium plays an important role in the reduced process.

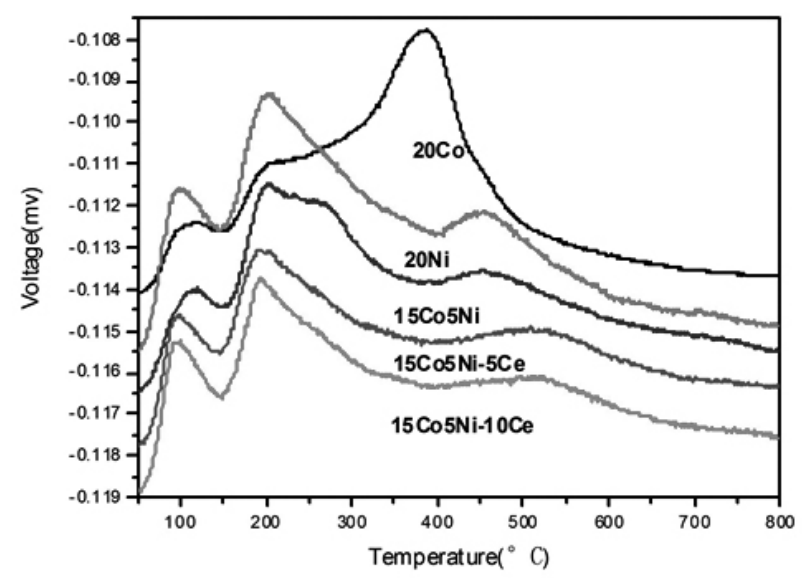

Fig.5 $\mathrm{H}_{2}$-TPD patterns of the different catalysts

\subsection{The selection of the catalyst}

The capability of five catalysts were performed at reaction temperature of $450^{\circ} \mathrm{C}$, the oil flow rate of $0.1 \mathrm{~mL} / \mathrm{min}$, reaction pressure of $2.5 \mathrm{MPa}$ and the $\mathrm{H}_{2}$ flow rate of $30 \mathrm{~mL} / \mathrm{min}$.

It can be seen from Figure 6 that each FT-IR spectrum had the strongest absorption band centered at $2930 \mathrm{~cm}^{-1}\left(\mathrm{CH}_{2}\right.$ stretching). Compared with the FT- IR graph of the crude oil, all cracking products have no $1740 \sim 1750$ $\mathrm{cm}^{-1}$ peak, while the carbonyl absorption peak of $1705 \sim 1720 \mathrm{~cm}^{-1}$ existed and the intensity of the absorption peak was weak, which showed that the liquid products have small amount of oxygenated compound. It can be found from Figure 6 that the peak intensity of $\mathrm{C}=\mathrm{O}$ of liquid products reduced as the following order: $15 \mathrm{Co} 5 \mathrm{Ni}-10 \mathrm{Ce}>15 \mathrm{Co} 5 \mathrm{Ni}-5 \mathrm{Ce}>15 \mathrm{Co} 5 \mathrm{Ni}>\mathrm{Co} 20>$ Ni20 in the range $1720 \mathrm{~cm}^{-1}$ to $1700 \mathrm{~cm}^{-1}$. The peak intensity of $\mathrm{C}=\mathrm{O}$ almost disappeared in the product produced on the $15 \mathrm{Co} 5 \mathrm{Ni}-10 \mathrm{Ce}$, which showed that the activity of the deoxidization was very efficient on the $15 \mathrm{Co} 5 \mathrm{Ni}-10 \mathrm{Ce}$. 
The FT- IR results are consistent with the result of $\mathrm{NH}_{3}-\mathrm{TPD}, \mathrm{H}_{2}$-TPD and GC-MS analysis. The $15 \mathrm{Co} 5 \mathrm{Ni}-10 \mathrm{Ce}$ catalyst had the best capability of the deoxidization in the conversion of vegetable oil to bio-fuels.

Gas yield, oxygenated compound, coke rate and liquid yield were shown and described in the table 2. As the table 2 displays, the content of oxygenated compound are high in the products of Co20, $15 \mathrm{Co} 5 \mathrm{Ni}$ and $\mathrm{Ni} 20$, and that oxygenated product content of Ni20 catalyst and Co20 catalyst are $5.45 \%, 4.38 \%$ and $4.68 \%$. Moreover, oxygenated compound content of the $15 \mathrm{Co} 5 \mathrm{Ni}-5 \mathrm{Ce}$ catalyst and the $15 \mathrm{Co} 5 \mathrm{Ni}-10 \mathrm{Ce}$ catalyst are $3.56 \%$ and $2.64 \%$, respectively. Oxygenated compound content is the lowest in the liquid product produced on the $15 \mathrm{Co} 5 \mathrm{Ni}-10 \mathrm{Ce}$ catalyst, and the total content of the alkanes and alkenes is the highest. Therefore, the $15 \mathrm{Co} 5 \mathrm{Ni}-10 \mathrm{Ce}$ catalyst in the five different catalysts is the best in the deoxygenated activity in the conversion of vegetable oil to bio-fuels. The GC-MS results are consistent with the $\mathrm{NH}_{3}$ TPD, $\mathrm{H}_{2}$-TPD and FT- IR analysis.

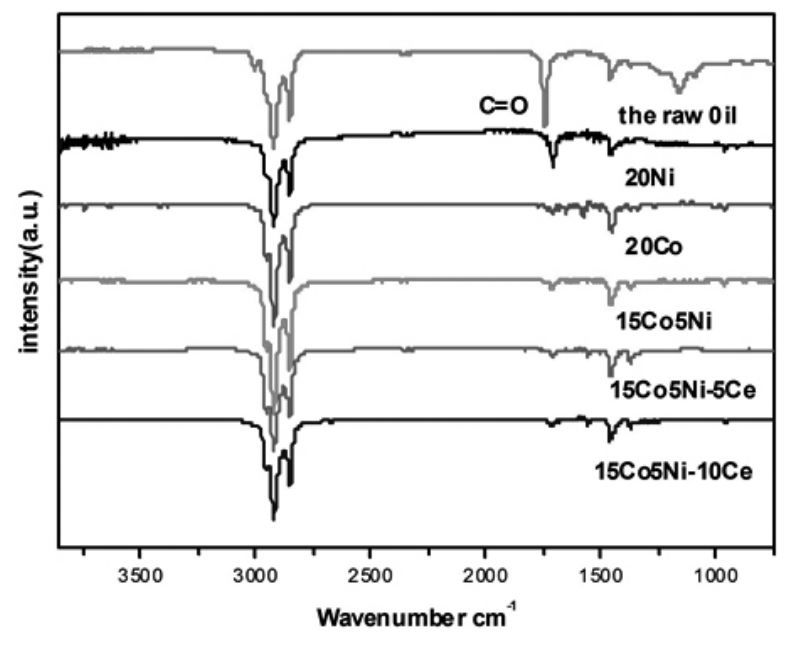

Fig.6 FT-IR spectra of the different liquid products on the different catalysts.

Table 2 the result of the conversion of vegetable oil to bio-fuels on different catalysts.

\begin{tabular}{|c|c|c|c|c|c|}
\hline & $\mathrm{Ni} 20$ & $\mathrm{Co} 20$ & $15 \mathrm{Co} 5 \mathrm{Ni}$ & $15 \mathrm{Co} 5 \mathrm{Ni}-5 \mathrm{Ce}$ & $15 \mathrm{Co} 5 \mathrm{Ni}-10 \mathrm{Ce}$ \\
\hline Liquid yield\% & 85.89 & 85.94 & 86.02 & 86.34 & 86.9 \\
\hline Gas yield \% & 12.08 & 12.13 & 12.36 & 12.24 & 11.89 \\
\hline $\mathrm{H}_{2} \mathrm{O} \%$ & 0.087 & 0.084 & 0.079 & 0.074 & 0.063 \\
\hline Coke yield \% & 1.94 & 1.85 & 1.54 & 1.35 & 1.15 \\
\hline \multicolumn{6}{|l|}{$\begin{array}{c}\text { Composition of the liquid } \\
\text { product }\end{array}$} \\
\hline aromatics & 7.54 & 6.44 & 6.63 & 5.89 & 5.96 \\
\hline alkanes & 40.4 & 42.57 & 42.93 & 43.05 & 46.51 \\
\hline alkenes & 46.33 & 45.89 & 45.66 & 47.13 & 44.68 \\
\hline Oxygenated product & 5.45 & 4.68 & 4.38 & 3.56 & 2.64 \\
\hline $\mathrm{C}_{8}-\mathrm{C}_{10} \mathrm{wt} \%$ & 10.89 & 10.8 & 10.59 & 8.42 & 5.23 \\
\hline $\mathrm{C}_{11}-\mathrm{C}_{18} \mathrm{wt} \%$ & 69.59 & 72.21 & 72.44 & 76.97 & 74.92 \\
\hline $\mathrm{C}_{18}{ }^{+} \mathrm{wt} \%$ & 19.24 & 16.59 & 16.57 & 14.24 & 19.64 \\
\hline Total, wt $\%$ & 99.72 & 99.58 & 99.6 & 99.63 & 99.79 \\
\hline
\end{tabular}

\subsection{Selection of the optimized condition}

Bio-fuels production was carried out by using the $15 \mathrm{Co} 5 \mathrm{Ni}-10 \mathrm{Ce}$ catalyst. During the experimental work, all kinds of factors were investigated from the reaction temperature, the oil flow rate, the reaction pressure and the gas flow rate.

\subsubsection{Effect of reaction temperature}

The experiments of several different reaction temperatures were performed from $470^{\circ} \mathrm{C}$ to $370^{\circ} \mathrm{C}$. The products of six different reaction temperatures were obtained at reaction pressure of $2.5 \mathrm{MPa}$, the crude oil flow rate of $0.1 \mathrm{~mL} / \mathrm{min}$ and the $\mathrm{H}_{2}$ flow rate of $30 \mathrm{~mL} / \mathrm{min}$, respectively. Liquid yield, gas yield, $\mathrm{H}_{2} \mathrm{O}$ content, coke deposition rate and the distribution of liquid hydrocarbons were described and shown in table 3 . As table 3 display, when reaction temperature reduced, liquid yield of the products of six different reaction temperatures had tiny aggrandizement, and the alkanes content of liquid products had biggish aggrandizement, and the coke deposition rate at different reaction temperatures increased more than 2 times. The content of oxygenated compound and $\mathrm{H}_{2} \mathrm{O}$ increased more than four times, which showed that reaction temperatures is a very important factor in bio-fuels producing from coke rate, oxygenated product content and $\mathrm{H}_{2} \mathrm{O}$ content. 
Table 3 the analytical result of the conversion of triglycerides to bio-fuels at different reaction temperatures.

\begin{tabular}{|c|c|c|c|c|c|c|}
\hline & $470^{\circ} \mathrm{C}$ & $450^{\circ} \mathrm{C}$ & $430^{\circ} \mathrm{C}$ & $410^{\circ} \mathrm{C}$ & $390^{\circ} \mathrm{C}$ & $370^{\circ} \mathrm{C}$ \\
\hline Liquid yield\% & 85.94 & 86.9 & 87.08 & 87.63 & 87.94 & 88.1 \\
\hline Gas $\%$ & 12.89 & 11.89 & 11.49 & 10.72 & 10.13 & 9.39 \\
\hline $\mathrm{H}_{2} \mathrm{O} \%$ & 0.037 & 0.063 & 0.087 & 0.126 & 0.138 & 0.145 \\
\hline Coke yield \% & 1.13 & 1.15 & 1.34 & 1.52 & 1.79 & 2.36 \\
\hline \multicolumn{7}{|c|}{ Composition of the liquid product } \\
\hline Cyclic compounds & 7.42 & 5.96 & 5.89 & 3.8 & 3.8 & 6.74 \\
\hline alkanes & 48.45 & 46.51 & 42.91 & 39.94 & 31.43 & 30.68 \\
\hline alkenes & 41.72 & 44.68 & 46.98 & 45.22 & 53.66 & 51.24 \\
\hline Oxygenated compounds & 2.28 & 2.64 & 4.02 & 10.53 & 10.77 & 10.88 \\
\hline $\mathrm{C}_{8}-\mathrm{C}_{10} \mathrm{wt} \%$ & 7.14 & 5.23 & 6.96 & 2.87 & 3.8 & 6.61 \\
\hline $\mathrm{C}_{11}-\mathrm{C}_{18} \mathrm{wt} \%$ & 71.36 & 74.92 & 70.26 & 63.93 & 73.97 & 69.78 \\
\hline $\mathrm{C}_{18}{ }^{+} \mathrm{wt} \%$ & 21.37 & 19.64 & 22.58 & 32.46 & 22.08 & 23.15 \\
\hline Total, wt $\%$ & 99.87 & 99.79 & 99.8 & 99.49 & 99.56 & 99.54 \\
\hline
\end{tabular}

When the temperature was raised, liquid yield reduced and gas yield increased, and the total content of oxygenated compound became lower. The total content of alkanes and alkenes in the products produced at $410^{\circ} \mathrm{C}, 390^{\circ} \mathrm{C}$ and $370^{\circ} \mathrm{C}$ are lower than the $430^{\circ} \mathrm{C}, 450^{\circ} \mathrm{C}$ and $470^{\circ} \mathrm{C}$ products, and the content of oxygenated compound and coke deposition rate are higher. Moreover, the total alkanes and alkenes content are higher in the products produced at $470^{\circ} \mathrm{C}$ and $450^{\circ} \mathrm{C}$, and the total content of oxygenated compound is low, and the main products are the hydrocarbon compounds under $\mathrm{C}_{18}$. Although the content of oxygenated compound in the $470^{\circ} \mathrm{C}$ product was the lowest in all products, liquid yield and total content of alkanes and alkenes were lower than the product produced at $450^{\circ} \mathrm{C}$. What' more, gas yield and total content of aromatic hydrocarbon and cyclic compound in the $470^{\circ} \mathrm{C}$ product was higher than the $450^{\circ} \mathrm{C}$ liquid product. The optimized reaction temperature is $450^{\circ} \mathrm{C}$.

It can be seen from Figure 7, all kinds of FT-IR spectrum were normalized by the strongest intensity of the absorption band centered at $2930 \mathrm{~cm}^{-1}$. Compared with FT- IR graph of the crude oil, the intensity of the $\mathrm{C}=\mathrm{O}$ bond stretch in the $1740 \sim 1750 \mathrm{~cm}^{-1}$ almost disappeared in the $410^{\circ} \mathrm{C}$, $430^{\circ} \mathrm{C}, 450^{\circ} \mathrm{C}$ and $470^{\circ} \mathrm{C}$ liquid products while the carbonyl absorption peak of $1705 \sim 1720 \mathrm{~cm}^{-1}$ exists, which shows that the liquid products have tiny compound containing oxygen. The carbonyl absorption peak is weak and decreasing when the reaction temperature was raised from $370^{\circ} \mathrm{C}$ to $470^{\circ} \mathrm{C}$. But the intensity of the absorption peak in the area of $1740 \sim 1750 \mathrm{~cm}^{-1}$ is strong, and the intensity of the absorption peak in the area of $3340 \sim 3320$ $\mathrm{cm}^{-1}$ is weak in the products produced at $370^{\circ} \mathrm{C}$ and $390^{\circ} \mathrm{C}$, which showed that the liquid products have tiny fatty acids derivatives containing oxygen. The result is in agreement with literature and in particular with the work of Katikaneni S. P. R et al. ${ }^{29}$ and Vonghia E. et al. ${ }^{30}$. The fatty acid and the enol are unstable intermediate products when the reaction temperature increased. When the reaction temperature increases, the kinetic energy of the molecules increased, and molecular effective collision increase, and that the effect of the decarboxylation $\left(-\mathrm{CO}_{2}\right)$ and the decarbonylation (-CO) are advanced. The carbonyl absorption peak of $1705 \sim 1720 \mathrm{~cm}^{-1}$ disappeared when the reaction temperature was $450^{\circ} \mathrm{C}$. The FT-IR result showed that the activity of deoxidization was very efficient at $450^{\circ} \mathrm{C}$, and reaction temperature is a very important factor in bio-fuel producing.

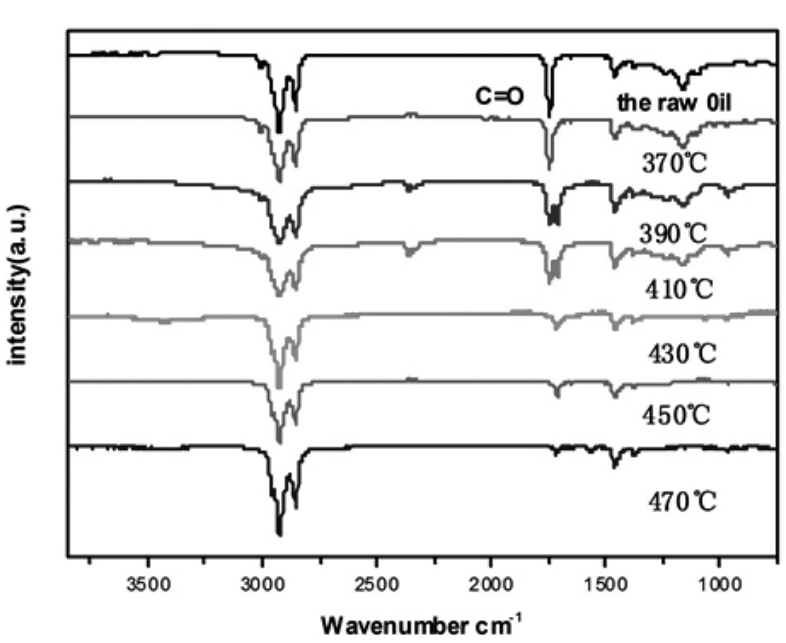

Fig.7 FT-IR spectra of the liquid products of different reaction temperatures

The distribution of $\mathrm{CO}$ and $\mathrm{CO}_{2}$ were listed in table 4 under various conditions. It can be seen from table 4 , the proportional relationship of $\mathrm{CO}$ and $\mathrm{CO}_{2}$ is changing with the time. The molar ratio of $\mathrm{CO}_{2} / \mathrm{CO}$ increased firstly and then decreased as the reaction progresses. But the molar ratio of $\mathrm{CO}_{2} / \mathrm{CO}$ is more than twice in most cases, and the molar ratio of $\mathrm{CO}_{2} / \mathrm{CO}$ change at about $0.88 \sim 24.54$. The molar ratio of $\mathrm{CO}_{2} / \mathrm{CO}$ may changed more than five times in the middle period (for 5 8 times). This is in agreement with literature and in particular with the work of Kovács S. et al ${ }^{35}$. The reaction of the decarboxylation and the decarbonylation occured at the same time and the decarboxylation reaction was the main reaction. Analytical result of GC online and $\mathrm{H}_{2} \mathrm{O}$ test indecated that the most oxygen in the crude oil were rejected by the forms of $\mathrm{CO}$ and $\mathrm{CO}_{2}$, and small part was rejected by the form of $\mathrm{H}_{2} \mathrm{O}$. 
Table 4 the GC result of the conversion of oil to bio-fuels at different reaction temperatures.

\begin{tabular}{|c|c|c|c|c|c|c|}
\hline & $470^{\circ} \mathrm{C}$ & $450^{\circ} \mathrm{C}$ & $430^{\circ} \mathrm{C}$ & $410^{\circ} \mathrm{C}$ & $390^{\circ} \mathrm{C}$ & $370^{\circ} \mathrm{C}$ \\
\hline No. & $\mathrm{CO}_{2} / \mathrm{CO}$ & $\mathrm{CO}_{2} / \mathrm{CO}$ & $\mathrm{CO}_{2} / \mathrm{CO}$ & $\mathrm{CO}_{2} / \mathrm{CO}$ & $\mathrm{CO}_{2} / \mathrm{CO}$ & $\mathrm{CO}_{2} / \mathrm{CO}^{\circ}$ \\
\hline 1 & 3.68 & 3.56 & 2.84 & 1.87 & 0.97 & 0.88 \\
\hline 2 & 6.09 & 5.87 & 3.16 & 3.03 & 1.46 & 1.25 \\
\hline 3 & 8.79 & 9.67 & 5.66 & 4.89 & 2.46 & 1.69 \\
\hline 4 & 14.74 & 12.15 & 7.10 & 6.78 & 2.85 & 2.09 \\
\hline 5 & 18.29 & 14.18 & 10.28 & 11.37 & 4.87 & 3.61 \\
\hline 6 & 24.54 & 13.25 & 14.36 & 13.28 & 7.56 & 3.87 \\
\hline 7 & 15.54 & 10.76 & 10.68 & 11.87 & 8.05 & 3.32 \\
\hline 8 & 12.75 & 7.45 & 7.55 & 9.87 & 7.43 & 2.67 \\
\hline 9 & 6.35 & 4.45 & 6.13 & 5.56 & 4.38 & 2.45 \\
\hline 10 & 4.28 & 3.11 & 3.24 & 3.18 & 2.97 & 1.46 \\
\hline
\end{tabular}

2.7.2 Effect of different oil flow rates

The experiments of several different oil flow rates were performed from $0.16 \mathrm{~mL} / \mathrm{min}$ to $0.06 \mathrm{~mL} / \mathrm{min}$. The experiments of several crude oil flow rates were performed at reaction pressure of $2.5 \mathrm{MPa}$, reaction temperature of $450^{\circ} \mathrm{C}$ and the $\mathrm{H}_{2}$ flow rate of $30 \mathrm{~mL} / \mathrm{min}$. Liquid yield, gas yield, $\mathrm{H}_{2} \mathrm{O}$ content, coke deposition rate and the distribution of liquid hydrocarbons were described and shown in table 5 . When the crude oil flow rate decreased from $0.16 \mathrm{~mL} / \mathrm{min}$ to $0.06 \mathrm{~mL} / \mathrm{min}$, the change of the liquid yield and $\mathrm{H}_{2} \mathrm{O}$ content is small, and the change of oxygenated compound content and coke yield increased more than twice, and the alkanes content of liquid products have biggish aggrandizement, which showed that oil velocity is a very important factor in bio-fuels producing.

Compared with the other products produced at $0.10 \mathrm{~mL} / \mathrm{min}, 0.08 \mathrm{~mL} /$ $\min$ and $0.06 \mathrm{~mL} / \mathrm{min}$ oil speed, the total content of alkanes and alkenes in the products produced at $0.16 \mathrm{~mL} / \mathrm{min}, 0.14 \mathrm{~mL} / \mathrm{min}$ and $0.12 \mathrm{~mL} / \mathrm{min}$ oil speed are lower, and the content of oxygenated compound of their products are higher. Their products are easy to be oxidized and have poor liquidity. When the oil flow rates are increased, the crude material and other middle product stay time became shorter, and the effect of the decarboxylation and the decarbonylation reaction would get bad. The total content of alkanes and alkenes in the products produced at $0.10 \mathrm{~mL} / \mathrm{min}, 0.08 \mathrm{~mL} / \mathrm{min}$ and $0.06 \mathrm{~mL} / \mathrm{min}$ oil speeds are $91.19 \%, 93.82 \%$ and $91.64 \%$, respectively. The main products are hydrocarbon compounds under $\mathrm{C}_{18}$, moreover, odd carbon hydrocarbon with $\mathrm{C}_{15}$ and $\mathrm{C}_{17}$ are the main compounds. The oxygenated compound content is $2.64 \%, 2.45 \%$ and $2.44 \%$, which showed that the activity of the deoxidization was very efficient at the $0.1 \mathrm{~mL} / \mathrm{min}, 0.08 \mathrm{~mL} / \mathrm{min}$ and $0.06 \mathrm{~mL} / \mathrm{min}$ oil velocity. From the LHSV, liquid yield, gas yield and economic benefit, the oil velocity with $0.10 \mathrm{~mL} / \mathrm{min}$ is suitable.

Table 5 the analytical result of the conversion of oil to bio-fuels at different oil flow rates.

\begin{tabular}{|c|c|c|c|c|c|c|}
\hline & 0.16 & 0.14 & 0.12 & 0.10 & 0.08 & 0.06 \\
\hline Liquid yield \% & 88.32 & 88.11 & 87.04 & 86.9 & 86.51 & 85.9 \\
\hline Gas $\%$ & 8.05 & 10.2 & 11.55 & 11.89 & 12.35 & 12.97 \\
\hline $\mathrm{H}_{2} \mathrm{O} \%$ & 1.37 & 0.097 & 0.078 & 0.063 & 0.054 & 0.058 \\
\hline Coke yield \% & 2.26 & 1.59 & 1.33 & 1.15 & 1.08 & 1.07 \\
\hline \multicolumn{7}{|l|}{ Composition of the liquid product } \\
\hline Cyclic compounds & 5.59 & 3.48 & 5.18 & 5.96 & 4.52 & 5.64 \\
\hline alkanes & 39.18 & 39.26 & 40.81 & 46.51 & 46.66 & 47.2 \\
\hline alkenes & 49.24 & 52.61 & 50.89 & 44.68 & 46.16 & 44.44 \\
\hline Oxygenated compounds & 5.53 & 4.45 & 2.84 & 2.64 & 2.45 & 2.44 \\
\hline $\mathrm{C}_{8}-\mathrm{C}_{10} \mathrm{wt} \%$ & 3.1 & 2.77 & 5.52 & 5.23 & 6.79 & 5.87 \\
\hline $\mathrm{C}_{11}-\mathrm{C}_{18} \mathrm{wt} \%$ & 66.84 & 63.23 & 69.33 & 74.92 & 71.21 & 68.06 \\
\hline $\mathrm{C}_{18}+\mathrm{wt}_{\mathrm{o}} \%$ & 29.6 & 33.8 & 24.87 & 19.64 & 21.79 & 25.79 \\
\hline Total, wt $\%$ & 99.54 & 99.74 & 99.72 & 99.79 & 99.79 & 99.72 \\
\hline
\end{tabular}

It can be seen from Fig.8, the intensity of the absorption peak decreased when the oil velocity reduced. Compared with FT- IR graph of the crude oil, most cracking products except the products produced at $0.16 \mathrm{~mL} / \mathrm{min}$ and 0.14 $\mathrm{mL} / \mathrm{min}$ oil velocity almost have no $1740 \sim 1750 \mathrm{~cm}^{-1}$ peak, but the carbonyl absorption peak of $1705 \sim 1720 \mathrm{~cm}^{-1}$ exists, which showed that the products have small amount of ketone compound. The peak intensity of $\mathrm{C}=\mathrm{O}$ almost disappeared in the liquid product produced at $0.1 \mathrm{~mL} / \mathrm{min}$ oil velocity. The FTIR result showed that the effect of the deoxidization was very efficient at the crude oil velocity of $0.1 \mathrm{~mL} / \mathrm{min}$. The intensity of the absorption peak in the area of $1740 \sim 1750 \mathrm{~cm}^{-1}$ is strong in the liquid products produced at $0.16 \mathrm{~mL} /$ $\min$ and $0.14 \mathrm{~mL} / \mathrm{min}$ oil velocity, and the intensity of the absorption peak in the range of $3340 \sim 3320 \mathrm{~cm}^{-1}$ is weak, which showed that the product produced at $0.16 \mathrm{~mL} / \mathrm{min}$ and $0.14 \mathrm{~mL} / \mathrm{min}$ have small amount of ketone and fatty acids derivatives containing oxygen. The FT-IR results are consistent with the GCMS data analysis, which showed that reaction oil velocity among $0.06 \mathrm{~mL} / \mathrm{min}$ to $0.16 \mathrm{~mL} / \mathrm{min}$ is an important factor in bio-fuels producing. 


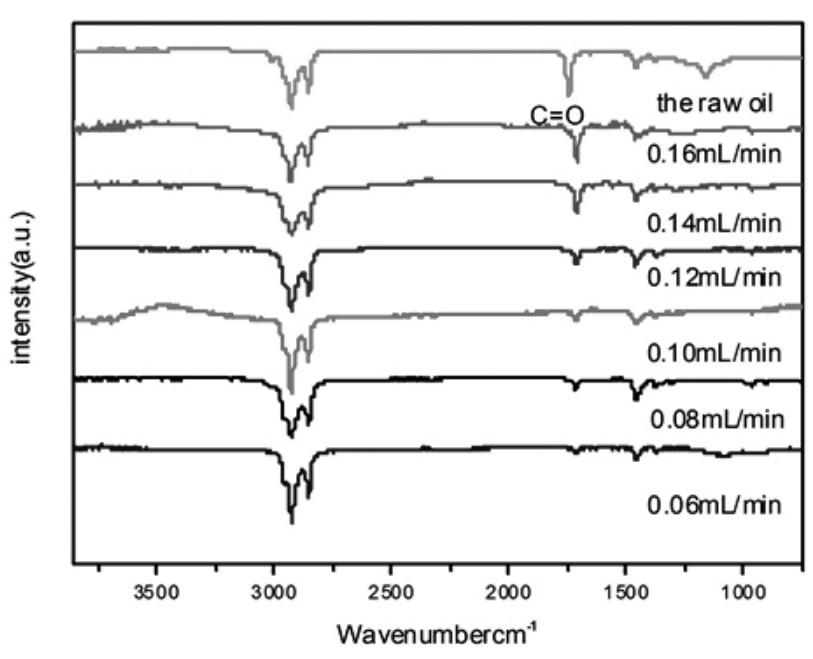

Fig.8 FT-IR spectra of the liquid products of different oil flow rates

The molar ratio of $\mathrm{CO}$ and $\mathrm{CO}_{2}$ are listed in table 6 under various conditions. It can be seen from table 6 , the proportional relationship of $\mathrm{CO}$ and $\mathrm{CO}$ is changing with the time. The molar ratio of $\mathrm{CO}_{2} / \mathrm{CO}$ increased firstly and then decreased as the reaction progresses. But the molar ratio of $\mathrm{CO}_{2} / \mathrm{CO}$ is more than twice in most cases, and the molar ratio of $\mathrm{CO}_{2} / \mathrm{CO}$ change at about $0.87 \sim 28.63$. The molar ratio of $\mathrm{CO}_{2} / \mathrm{CO}$ may change more than five times more than five times for $3 \sim 8$ times in the collected gas.

Table 6 the GC analytical result of different oil flow rates.

\begin{tabular}{|c|c|c|c|c|c|c|}
\hline & 0.16 & 0.14 & 0.12 & 0.10 & 0.08 & 0.06 \\
\hline $\mathrm{No}$. & $\mathrm{CO}_{2} / \mathrm{CO}$ & $\mathrm{CO}_{2} / \mathrm{CO}$ & $\mathrm{CO}_{2} / \mathrm{CO}$ & $\mathrm{CO}_{2} / \mathrm{CO}$ & $\mathrm{CO}_{2} / \mathrm{CO}$ & $\mathrm{CO}_{2} / \mathrm{CO}$ \\
\hline 1 & 0.87 & 1.68 & 1.71 & 3.56 & 3.75 & 2.28 \\
\hline 2 & 1.22 & 3.29 & 2.00 & 5.87 & 5.53 & 6.29 \\
\hline 3 & 7.51 & 6.09 & 5.62 & 9.67 & 6.10 & 9.00 \\
\hline 4 & 9.60 & 8.84 & 8.80 & 12.15 & 7.92 & 14.02 \\
\hline 5 & 11.68 & 9.12 & 18.81 & 14.18 & 10.76 & 28.63 \\
\hline 6 & 10.45 & 18.09 & 14.35 & 13.25 & 11.74 & 27.7 \\
\hline 7 & 6.68 & 13.74 & 11.14 & 10.76 & 18.16 & 15.53 \\
\hline 8 & 3.08 & 5.76 & 8.78 & 7.45 & 10.16 & 9.37 \\
\hline 9 & 2.06 & 2.69 & 6.94 & 4.45 & 5.72 & 7.84 \\
\hline 10 & 1.48 & 2.39 & 3.56 & 3.11 & 4.34 & 4.54 \\
\hline
\end{tabular}

2.7.3 Effect of different reaction pressures

The experiments of different reaction pressures were performed from 3.5 $\mathrm{MPa}$ to $1.0 \mathrm{MPa}$. All kinds of the products were obtained at oil flow rate of $0.1 \mathrm{~mL} / \mathrm{min}$, reaction temperature of $450{ }^{\circ} \mathrm{C}$ and the carrier gas flow rate of $30 \mathrm{~mL} / \mathrm{min}$. Liquid yield, gas yield, $\mathrm{H}_{2} \mathrm{O}$ content, coke rate and the distribution of liquid hydrocarbons were described and shown in table 7 . The change of liquid yield, $\mathrm{H}_{2} \mathrm{O}$ content and coke rate is small from $3.5 \mathrm{MPa}$ to $1.0 \mathrm{MPa}$. The change of oxygenated compound content increased from $2.62 \%$ to $3.38 \%$, which showed that the activity of the deoxidization and the hydrogenation was very efficient among $3.5 \mathrm{MPa}$ to $1.0 \mathrm{MPa}$.

According to the data of GC-MS, the total content of alkanes and alkenes in the products produced at $3.5 \mathrm{MPa}, 3.0 \mathrm{MPa}$ and $2.5 \mathrm{MPa}$ are $91.54 \%$, $92.53 \%$ and $91.19 \%$, respectively. The main products are hydrocarbon compounds under $\mathrm{C}_{18}$, and odd carbon hydrocarbon with $\mathrm{C}_{15}$ and $\mathrm{C}_{17}$ are the main compounds. The total content of alkanes and alkenes in the product produced at 3.0 $\mathrm{MPa}$ is higher than other products produced at other reaction pressure. Moreover, the content of alkanes in the product produced at 3.0 $\mathrm{MPa}$ is $50.19 \%$. What's more, the oxygenated compound content is $2.62 \%$, which showed that the activity of the deoxidization and the hydrogenation was very efficient at 3.0 MPa, which showed that reaction pressure with 3.0 MP is suitable among 1.0 MPa to $3.5 \mathrm{MPa}$ under the same LHSV condition. 
J. Chil. Chem. Soc., 60, No 4 (2015)

Table 7 the analytical result of different reaction pressures.

\begin{tabular}{|c|c|c|c|c|c|c|}
\hline & 3.5 & 3.0 & 2.5 & 2.0 & 1.5 & 1.0 \\
\hline Liquid yield\% & 87.05 & 87.08 & 86.9 & 86.63 & 86.71 & 86.30 \\
\hline Gas\% & 11.79 & 11.78 & 11.89 & 12.04 & 11.86 & 12.09 \\
\hline $\mathrm{H}_{2} \mathrm{O} \%$ & 0.059 & 0.055 & 0.063 & 0.067 & 0.061 & 0.073 \\
\hline Coke\% & 1.1 & 1.08 & 1.15 & 1.26 & 1.36 & 1.53 \\
\hline Composition of the liquid product & & & & & & 6.72 \\
\hline aromatics & 5.64 & 4.60 & 5.96 & 5.67 & 7.36 & 43.88 \\
\hline alkanes & 50.1 & 50.19 & 46.51 & 46.3 & 46.05 & 45.62 \\
\hline alkenes & 41.44 & 42.36 & 44.68 & 44.43 & 43.16 & 3.38 \\
\hline oxygenates $^{2} \mathrm{C}_{8}{ }^{-\mathrm{C}_{10} \mathrm{wt} \%}$ & 2.64 & 2.62 & 2.64 & 3.14 & 3.08 & 6.61 \\
\hline $\mathrm{C}_{11}{ }^{-\mathrm{C}_{17} \mathrm{wt} \%}$ & 5.87 & 5.17 & 5.23 & 5.86 & 6.61 & 68.44 \\
\hline $\mathrm{C}_{18}{ }^{+} \mathrm{wt} \%$ & 72.26 & 75.08 & 74.92 & 69.49 & 69.31 & 24.55 \\
\hline total\% & 21.69 & 20.52 & 19.64 & 24.19 & 23.73 & 99.60 \\
\hline
\end{tabular}

The distribution of $\mathrm{CO}$ and $\mathrm{CO}_{2}$ are listed in table 8 under various conditions. It can be seen from table 8 , the proportional relationship between $\mathrm{CO}_{\text {and }} \mathrm{CO}_{2}$ is changing with the time. The molar ratio of $\mathrm{CO} / \mathrm{CO}_{2}$ increased firstly and then decreased as the reaction progresses. $\mathrm{But}$ the molar ratio of $\mathrm{CO} / \mathrm{CO}$ is more than three times in most cases, and the molar ratio of $\mathrm{CO}_{2} / \mathrm{CO}$ changed at about 1.12 25.46.

The analytical results of $\mathrm{GC}$ online and trace $\mathrm{H}_{2} \mathrm{O}$ test indicated that the most oxygen in the oil were rejected by the forms of $\mathrm{CO}$ and $\mathrm{CO}_{2}$, and the minor oxygen were rejected by the form of $\mathrm{H}_{2} \mathrm{O}$.

Table 8 the GC result of different reaction pressures.

\begin{tabular}{|c|c|c|c|c|c|c|}
\hline & $3.5 \mathrm{MPa}$ & $3.0 \mathrm{MPa}$ & $2.5 \mathrm{MPa}$ & $2.0 \mathrm{MPa}$ & $1.5 \mathrm{MPa}$ & $1.0 \mathrm{MPa}$ \\
\hline No. & $\mathrm{CO}_{2} / \mathrm{CO}$ & $\mathrm{CO}_{2} / \mathrm{CO}$ & $\mathrm{CO}_{2} / \mathrm{CO}$ & $\mathrm{CO}_{2} / \mathrm{CO}$ & $\mathrm{CO}_{2} / \mathrm{CO}$ & $\mathrm{CO}_{2} / \mathrm{CO}$ \\
\hline 1 & 4.34 & 3.68 & 3.56 & 2.24 & 1.69 & 1.12 \\
\hline 2 & 6.09 & 6.09 & 5.87 & 5.82 & 5.15 & 1.87 \\
\hline 3 & 10.56 & 7.92 & 9.67 & 8.36 & 7.84 & 2.85 \\
\hline 4 & 17.89 & 8.79 & 12.15 & 10.91 & 10.94 & 8.86 \\
\hline 5 & 19.28 & 13.74 & 14.18 & 11.61 & 12.69 & 9.53 \\
\hline 6 & 25.46 & 18.09 & 13.25 & 13.44 & 13.62 & 11.62 \\
\hline 7 & 23.24 & 12.54 & 10.76 & 9.67 & 9.55 & 10.29 \\
\hline 8 & 13.45 & 8.75 & 7.45 & 7.87 & 5.81 & 6.86 \\
\hline 9 & 8.96 & 6.35 & 4.45 & 5.68 & 5.12 & 5.56 \\
\hline 10 & 6.47 & 3.28 & 3.11 & 3.56 & 1.63 & 2.86 \\
\hline
\end{tabular}

It can be found from Fig.9 that the peak intensity of $\mathrm{C}=\mathrm{O}$ bond of liquid products reduced as the following order: $3.5 \mathrm{MPa} \geq 3.0 \mathrm{MPa}>2.5 \mathrm{MPa}>2.0 \mathrm{MPa}$ $>1.5 \mathrm{MPa}>1.0 \mathrm{MPa}$ in the range $1705 \sim 1720 \mathrm{~cm}^{-1}$, and the peak intensity of $\mathrm{C}=\mathrm{O}$ almost disappeared in the product produced at $3.0 \mathrm{MPa}$. The result of FT-IR showed that the activity of the deoxidization and the hydrogenation was very efficient at 3.0MPa. 


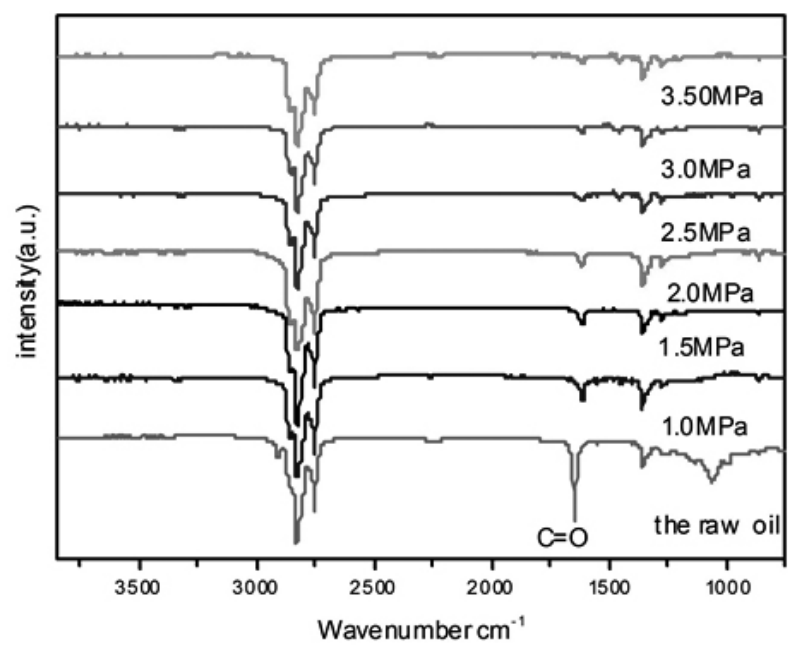

Fig.9 FT-IR spectra of the liquid products of different reaction pressures

\subsubsection{Effect of different $\mathrm{H}_{2}$ flow rates}

The tests of several $\mathrm{H}_{2}$ flow rate were performed at $\mathrm{H}_{2}$ flow rate from 15 $\mathrm{mL} / \mathrm{min}$ to $40 \mathrm{~mL} / \mathrm{min}$. The products of various $\mathrm{H}_{2}$ flow rates were obtained at reaction pressure of $2.5 \mathrm{MPa}$, reaction temperature of $450^{\circ} \mathrm{C}$ and the oil flow rate of $0.10 \mathrm{~mL} / \mathrm{min}$. Liquid yield, gas yield, $\mathrm{H}_{2} \mathrm{O}$ content, coke rate and the distribution of liquid hydrocarbons were described and shown in table 9. As table 9 displays, the change of liquid yield, $\mathrm{H}_{2} \mathrm{O}$ content, the content of alkanes and coke deposition rate is small, which showed that $\mathrm{H}_{2}$ velocity is a secondary factor in the conversion of triglyceride to bio-fuels.

As table 9 display, the total content of alkanes and alkenes in the liquid product produced at $35 \mathrm{~mL} / \mathrm{min}$ is $93.26 \%$, and the content of alkanes is the highest and the content is $48.36 \%$, and the content of oxygenated compounds in the $35 \mathrm{~mL} / \mathrm{min}$ liquid product is lower than other $\mathrm{H}_{2}$ flow rates products. The main products are hydrocarbon compounds under ${ }^{2} \mathrm{C}_{18}$, and odd carbon hydrocarbon with $\mathrm{C}_{15}$ and $\mathrm{C}_{17}$ are the main compounds. Although the content of alkanes in the liquid product produced at $40 \mathrm{~mL} / \mathrm{min}$ is $48.09 \%$, the content of oxygenated compounds and coke rate in the $40 \mathrm{~mL} / \mathrm{min}$ liquid product is higher than the liquid product produced at $35 \mathrm{~mL} / \mathrm{min}$. When the $\mathrm{H}_{2}$ flow rate increased, the crude oil and other middle products stay time become short, and the activity of decarboxylation and decarbonylation reaction would not be good. The good technique is that $\mathrm{H}_{2}$ flow rate is $35 \mathrm{~mL} / \mathrm{min}$ from the consumption of $\mathrm{H}_{2}$, liquid products yield, the total content of alkanes and alkenes, coke rate and the content of oxygenated compounds.

Table 9 the analytical result of different gas flow rates.

\begin{tabular}{|c|c|c|c|c|c|c|}
\hline & 15 & 20 & 25 & 30 & 35 & 40 \\
\hline Liquid yield\% $\%$ & 86.06 & 86.12 & 87.03 & 86.9 & 87.06 & 86.16 \\
\hline Gas $\%$ & 12.48 & 12.46 & 11.74 & 11.89 & 11.79 & 12.65 \\
\hline $\mathrm{H}_{2} \mathrm{O} \%$ & 0.082 & 0.087 & 0.068 & 0.063 & 0.056 & 0.059 \\
\hline Coke yield $\%$ & 1.37 & 1.33 & 1.16 & 1.15 & 1.09 & 1.13 \\
\hline \multicolumn{7}{|c|}{ Composition of the liquid product } \\
\hline Cyclic compounds & 6.74 & 6.53 & 7.42 & 5.96 & 3.99 & 2.64 \\
\hline alkanes & 43.78 & 45.92 & 46.35 & 46.51 & 48.36 & 48.09 \\
\hline alkenes & 45.62 & 44.38 & 43.22 & 44.68 & 44.9 & 45.49 \\
\hline Oxygenated compound & 3.38 & 2.84 & 2.78 & 2.64 & 2.41 & 3.25 \\
\hline $\mathrm{C}_{9}-\mathrm{C}_{10} \mathrm{wt} \%$ & 6.61 & 4.91 & 6.94 & 5.23 & 4.61 & 4.81 \\
\hline $\mathrm{C}_{11}-\mathrm{C}_{18} \mathrm{wt} \%$ & 68.36 & 67.12 & 68.85 & 74.92 & 74.77 & 70.88 \\
\hline $\mathrm{C}_{18}^{+} \mathrm{wt} \%$ & 24.55 & 27.64 & 23.98 & 19.64 & 20.28 & 23.78 \\
\hline Total, wt $\%$ & 99.52 & 99.67 & 99.77 & 99.79 & 99.66 & 99.47 \\
\hline
\end{tabular}

It can be seen from Fig.10, all kinds of FT-IR spectrum were normalized by the strongest intensity of the absorption band centered at $2930 \mathrm{~cm}^{-1}$. Compared with FT- IR graph of the crude oil, all cracking products had no $1740 \sim 1750 \mathrm{~cm}^{-1}$ peak while the carbonyl absorption peak of $1705 \sim 1720 \mathrm{~cm}^{-1}$ existed and the intensity of the absorption peak was small, which showed that the product had small amount of derivatives containing oxygen and the activity of deoxidization was very efficient in the different $\mathrm{H}_{2}$ flow rates. Compared with the reaction temperature, $\mathrm{H}_{2}$ velocity was a secondary factor in producing bio-fuels.

The distribution of $\mathrm{CO}$ and $\mathrm{CO}_{2}$ are listed in table 10 under various conditions. It can be seen from table 10 , the proportional relationship between $\mathrm{CO}$ and $\mathrm{CO}_{2}$ is changing with time, and the molar ratio of $\mathrm{CO}_{2} / \mathrm{CO}$ changed at about 1.56 29.56. The molar ratio $\mathrm{CO}_{2} / \mathrm{CO}$ increased firstly and then decreased as the reaction progresses. But the molar ratio of $\mathrm{CO}_{2} / \mathrm{CO}$ was more than three times in most cases. The molar ratio of $\mathrm{CO}_{2} / \mathrm{CO}$ changed more than four times in the reaction middle period. The results of GC online and trace water test showed that the oxygen in the oil was mainly removed by the forms of $\mathrm{CO}$ and $\mathrm{CO}_{2}$, and a small quantity of oxygen was rejected by the form of $\mathrm{H}_{2} \mathrm{O}$.

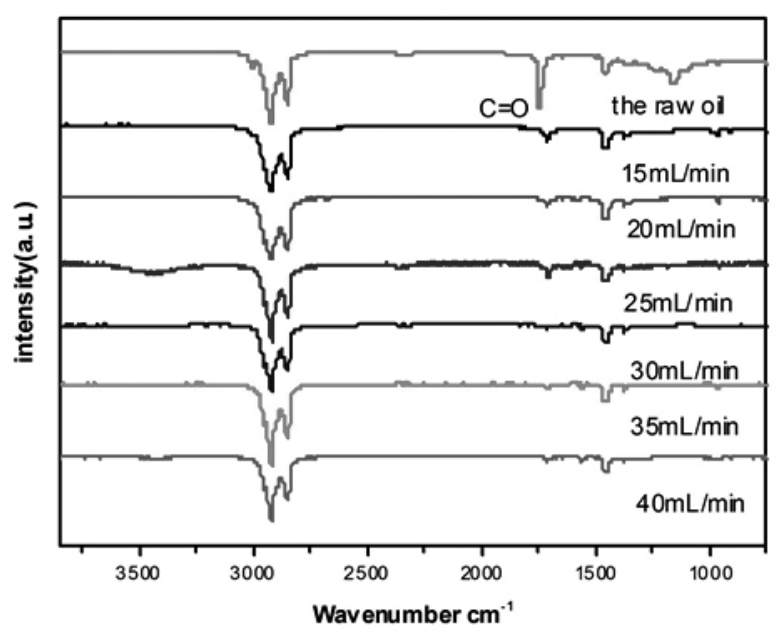

Fig.10 FT-IR spectra of the liquid products of different gas flow rates 
Table 10 the GC result of different gas flow rates

\begin{tabular}{|c|c|c|c|c|c|c|}
\hline & 15 & 20 & 25 & 30 & 35 & 40 \\
\hline No. & $\mathrm{CO}_{2} / \mathrm{CO}$ & $\mathrm{CO}_{2} / \mathrm{CO}$ & $\mathrm{CO}_{2} / \mathrm{CO}$ & $\mathrm{CO}_{2} / \mathrm{CO}$ & $\mathrm{CO}_{2} / \mathrm{CO}$ & $\mathrm{CO}_{2} / \mathrm{CO}$ \\
\hline 1 & 1.56 & 2.18 & 3.84 & 3.56 & 6.46 & 5.24 \\
\hline 2 & 2.68 & 2.95 & 5.08 & 5.87 & 10.35 & 9.88 \\
\hline 3 & 3.58 & 5.68 & 8.15 & 9.67 & 14.56 & 10.68 \\
\hline 4 & 5.89 & 9.87 & 10.46 & 12.15 & 20.35 & 11.24 \\
\hline 5 & 8.45 & 10.89 & 12.12 & 14.18 & 29.56 & 14.87 \\
\hline 6 & 6.36 & 10.75 & 11.15 & 13.25 & 25.45 & 12.54 \\
\hline 7 & 4.98 & 10.24 & 9.46 & 10.76 & 17.45 & 8.76 \\
\hline 8 & 3.56 & 8.45 & 8.45 & 7.45 & 15.35 & 7.45 \\
\hline 9 & 2.35 & 6.56 & 5.35 & 4.45 & 6.78 & 4.45 \\
\hline 10 & 2.14 & 2.84 & 3.22 & 3.11 & 4.26 & 2.47 \\
\hline
\end{tabular}

2.7.5 The optimized result of the conversion of vegetable oil to bio-fuels

The technique was optimized at reaction temperature of $450^{\circ} \mathrm{C}$, reaction pressure of $3.0 \mathrm{MPa}$, the oil flow rate of $0.1 \mathrm{~mL} / \mathrm{min}$ and the gas flow rate of 35 $\mathrm{mL} / \mathrm{min}$. The fresh and used catalysts were analyzed by BET. The molar ratio of $\mathrm{CO}_{2} / \mathrm{CO}$ may changed at about 5.05 26.85. The results of GC online showed that the reaction of the decarboxylation and the decarbonylation occurred at the same time and the decarboxylation reaction was the main reaction. The gas yield and liquid yield of liquid products were $11.79 \mathrm{wt} \%$ and $87.11 \mathrm{wt} \% ; \mathrm{H}_{2} \mathrm{O}$ content, oxygenated compound content and coke rate of liquid products were $0.053 \mathrm{wt} \%, 2.32 \mathrm{wt} \%$ and $1.05 \mathrm{wt} \%$; the alkanes content and alkenes content of liquid products were $50.02 \%$ and $40.03 \%$ under the optimized condition. The distribution in the liquid product analyzed by GC-MS was showed in table 11. The main products were hydrocarbon compounds under $\mathrm{C}_{18}$.

Table 11 the GC-MS analytical result of the conversion of oil to bio-fuels under the optimized condition

\begin{tabular}{|c|c|c|c|c|}
\hline No. & RT & Area $\%$ & molecular formula & chemical name \\
\hline 1 & 3.59 & 0.21 & $\mathrm{C}_{9} \mathrm{H}_{18}$ & 1-Nonene \\
\hline 2 & 3.699 & 0.53 & $\mathrm{C}_{9} \mathrm{H}_{20}$ & Nonane \\
\hline 3 & 3.779 & 0.11 & $\mathrm{C}_{9} \mathrm{H}_{18}$ & 2-Nonene,(E)- \\
\hline 4 & 4.924 & 0.2 & $\mathrm{C}_{9} \mathrm{H}_{12}$ & Benzene,1-ethyl-4-methyl- \\
\hline 5 & 5.015 & 0.32 & $\mathrm{C}_{10} \mathrm{H}_{20}$ & 1-Decene \\
\hline 6 & 5.141 & 0.83 & $\mathrm{C}_{10} \mathrm{H}_{22}$ & Decane \\
\hline 7 & 5.227 & 0.22 & $\mathrm{C}_{10} \mathrm{H}_{20}$ & 4-Decene,(E)- \\
\hline 8 & 6.085 & 0.3 & $\mathrm{C}_{10} \mathrm{H}_{14}$ & Benzene,butyl- \\
\hline 9 & 6.28 & 0.46 & $\mathrm{C}_{10} \mathrm{H}_{14}$ & Benzene,1-methyl-3-propyl- \\
\hline 10 & 6.566 & 0.97 & $\mathrm{C}_{11} \mathrm{H}_{22}$ & 5-Undecene,(E)- \\
\hline 11 & 6.692 & 0.91 & $\mathrm{C}_{11} \mathrm{H}_{24}$ & Undecane \\
\hline 12 & 6.772 & 0.45 & $\mathrm{C}_{11} \mathrm{H}_{22}$ & 4-Undecene,(E)- \\
\hline 13 & 6.915 & 0.23 & $\mathrm{C}_{11} \mathrm{H}_{22}$ & 3-Undecene,(E)- \\
\hline 14 & 7.132 & 0.19 & $\mathrm{C}_{11} \mathrm{H}_{22}$ & Cyclohexane,pentyl- \\
\hline 15 & 7.327 & 0.37 & $\mathrm{C}_{11} \mathrm{H}_{22}$ & Cyclopentane,hexyl- \\
\hline 17 & 7.561 & 0.22 & $\mathrm{C}_{10} \mathrm{H}_{12}$ & Indan,1-methyl- \\
\hline 18 & 7.636 & 0.52 & $\mathrm{C}_{11} \mathrm{H}_{16}$ & Benzene,pentyl- \\
\hline 19 & 7.767 & 0.57 & $\mathrm{C}_{10} \mathrm{H}_{12}$ & Naphthalene, 1,2,3,4-tetrahydro- \\
\hline 20 & 8.082 & 0.85 & $\mathrm{C}_{12} \mathrm{H}_{24}$ & 3-Dodecene,(Z)- \\
\hline 21 & 8.202 & 0.53 & $\mathrm{C}_{12} \mathrm{H}_{26}$ & Dodecane \\
\hline 22 & 8.282 & 0.29 & $\mathrm{C}_{12} \mathrm{H}_{24}$ & 6-Dodecene,(E)- \\
\hline 23 & 9.141 & 1.1 & $\mathrm{C}_{12} \mathrm{H}_{18}$ & Benzene, hexyl- \\
\hline 24 & 9.518 & 0.89 & $\mathrm{C}_{13} \mathrm{H}_{26}$ & 1-Tridecene \\
\hline 25 & 9.633 & 1.55 & $\mathrm{C}_{13} \mathrm{H}_{28}$ & Tridecane \\
\hline
\end{tabular}




\begin{tabular}{|c|c|c|c|c|}
\hline 26 & 9.702 & 0.22 & $\mathrm{C}_{13} \mathrm{H}_{26}$ & 3-Tridecene, $(Z)$ - \\
\hline 28 & 10.388 & 0.46 & $\mathrm{C}_{13} \mathrm{H}_{26}$ & 6-Tridecene,(E)- \\
\hline 29 & 10.525 & 0.82 & $\mathrm{C}_{13} \mathrm{H}_{20}$ & Benzene, heptyl- \\
\hline 30 & 10.64 & 0.28 & $\mathrm{C}_{13} \mathrm{H}_{20}$ & 1-Methyl-2-n-hexylbenzene \\
\hline 31 & 10.875 & 2.07 & $\mathrm{C}_{14} \mathrm{H}_{28}$ & 1-Tetradecene \\
\hline 32 & 10.978 & 3.1 & $\mathrm{C}_{14} \mathrm{H}_{30}$ & Tetradecane \\
\hline 33 & 11.184 & 0.1 & $\mathrm{C}_{14} \mathrm{H}_{28}$ & 5-Tetradecene,(E)- \\
\hline 34 & 11.647 & 0.22 & $\mathrm{C}_{14} \mathrm{H}_{28}$ & Cyclopentane, nonyl- \\
\hline 36 & 11.784 & 0.55 & $\mathrm{C}_{14} \mathrm{H}_{26}$ & Cyclopentene,1-octyl- \\
\hline 37 & 11.904 & 0.54 & $\mathrm{C}_{14} \mathrm{H}_{22}$ & Benzene, octyl- \\
\hline 38 & 11.973 & 0.21 & $\mathrm{C}_{14} \mathrm{H}_{22}$ & Benzene,(1-methylheptyl)- \\
\hline 39 & 12.151 & 3.72 & $\mathrm{C}_{15} \mathrm{H}_{30}$ & 1-Pentadecene \\
\hline 40 & 12.248 & 7.82 & $\mathrm{C}_{15} \mathrm{H}_{32}$ & Pentadecane \\
\hline 41 & 12.448 & 0.26 & $\mathrm{C}_{15} \mathrm{H}_{30}$ & Cyclopentane, decyl \\
\hline 42 & 12.923 & 1.23 & $\mathrm{C}_{15} \mathrm{H}_{30}$ & n-Nonylcyclohexane \\
\hline 43 & 13.163 & 1.11 & $\mathrm{C}_{16} \mathrm{H}_{32}$ & Z-7-Hexadecene \\
\hline 44 & 13.278 & 0.49 & $\mathrm{C}_{16} \mathrm{H}_{32}$ & 1-Hexadecene \\
\hline 45 & 13.352 & 0.82 & $\mathrm{C}_{16} \mathrm{H}_{32}$ & Z-8-Hexadecene \\
\hline 46 & 13.438 & 1.23 & $\mathrm{C}_{16} \mathrm{H}_{34}$ & Hexadecane \\
\hline 47 & 13.621 & 0.52 & $\mathrm{C}_{16} \mathrm{H}_{32}$ & 5-Hexadecene,(E)- \\
\hline 48 & 14.147 & 1.41 & $\mathrm{C}_{17} \mathrm{H}_{36}$ & Tetradecane,2,6,10-trimethyl- \\
\hline 49 & 14.21 & 0.79 & $\mathrm{C}_{17} \mathrm{H}_{34}$ & 1-Heptadecene \\
\hline 50 & 14.342 & 3.15 & $\mathrm{C}_{17} \mathrm{H}_{34}$ & 3-Heptadecene,(Z)- \\
\hline 51 & 14.405 & 4.42 & $\mathrm{C}_{17} \mathrm{H}_{34}$ & 8-Heptadecene \\
\hline 52 & 14.491 & 1.24 & $\mathrm{C}_{17} \mathrm{H}_{34}$ & 7-Heptadecene \\
\hline 53 & 14.577 & 6.3 & $\mathrm{C}_{17} \mathrm{H}_{36}$ & Heptadecane \\
\hline 54 & 14.76 & 1.13 & $\mathrm{C}_{17} \mathrm{H}_{34}$ & 3-Heptadecene,(E)- \\
\hline 55 & 14.868 & 0.95 & $\mathrm{C}_{12} \mathrm{H}_{24}$ & Cyclohexane,1-methyl-3-pentyl- \\
\hline 56 & 15.086 & 0.58 & $\mathrm{C}_{17} \mathrm{H}_{36}$ & Hexadecane,2-methyl- \\
\hline 57 & 15.2 & 1.3 & $\mathrm{C}_{17} \mathrm{H}_{34}$ & Cyclohexane,undecyl- \\
\hline 58 & 15.401 & 0.62 & $\mathrm{C}_{18} \mathrm{H}_{36}$ & 8-Octadecene \\
\hline 59 & 15.486 & 0.5 & $\mathrm{C}_{18} \mathrm{H}_{36}$ & 6-Octadecene,(E)- \\
\hline 60 & 15.572 & 0.83 & $\mathrm{C}_{18} \mathrm{H}_{36}$ & 1-Octadecene \\
\hline 61 & 15.647 & 1.95 & $\mathrm{C}_{18} \mathrm{H}_{38}$ & Octadecane \\
\hline 62 & 15.853 & 2.3 & $\mathrm{C}_{18} \mathrm{H}_{36}$ & 3-Octadecene,(E)- \\
\hline 63 & 16.379 & 0.16 & $\mathrm{C}_{19} \mathrm{H}_{38}$ & 5-Nonadecene(E)- \\
\hline 64 & 16.385 & 0.91 & $\mathrm{C}_{19} \mathrm{H}_{40}$ & Nonadecane \\
\hline 65 & 16.442 & 0.34 & $\mathrm{C}_{19} \mathrm{H}_{38}$ & 3-Nonadecene(E)- \\
\hline 66 & 16.499 & 0.39 & $\mathrm{C}_{19} \mathrm{H}_{38}$ & 5-Nonadecene(Z)- \\
\hline 67 & 16.717 & 3.02 & $\mathrm{C}_{18} \mathrm{H}_{36}$ & 4-Methyl-7-Heptadecene \\
\hline 68 & 16.734 & 0.22 & $\mathrm{C}_{17} \mathrm{H}_{34} \mathrm{O}$ & 2-Heptadecanone \\
\hline 69 & 17.312 & 5.4 & $\mathrm{C}_{18} \mathrm{H}_{36}$ & Heptadecane,8-methyl- \\
\hline 70 & 17.432 & 1.07 & $\mathrm{C}_{18} \mathrm{H}_{36}$ & Heptadecane,9-methyl- \\
\hline 71 & 17.655 & 3.91 & $\mathrm{C}_{20} \mathrm{H}_{42}$ & Eicosane \\
\hline 72 & 18.45 & 3.25 & $\mathrm{C}_{21} \mathrm{H}_{42}$ & Heneicosene \\
\hline 73 & 18.582 & 0.65 & $\mathrm{C}_{21} \mathrm{H}_{44}$ & Heneicosane \\
\hline
\end{tabular}




\begin{tabular}{|c|c|c|c|c|}
\hline 74 & 18.656 & 1.03 & $\mathrm{C}_{19} \mathrm{H}_{38} \mathrm{O}$ & 2-Nonadecanone \\
\hline 75 & 19.017 & 4.65 & $\mathrm{C}_{21} \mathrm{H}_{44}$ & Eicosane,3-methyl \\
\hline 76 & 19.166 & 2.32 & $\mathrm{C}_{22} \mathrm{H}_{44}$ & 1-Docosene \\
\hline 77 & 19.349 & 2.29 & $\mathrm{C}_{22} \mathrm{H}_{46}$ & Docosane \\
\hline 78 & 19.509 & 0.97 & $\mathrm{C}_{22} \mathrm{H}_{44}$ & 10-Docosene \\
\hline 79 & 20.03 & 0.9 & $\mathrm{C}_{22} \mathrm{H}_{46}$ & Heneicosane,5-methyl- \\
\hline 80 & 20.087 & 0.67 & $\mathrm{C}_{22} \mathrm{H}_{46}$ & Heneicosane,7-methyl- \\
\hline 81 & 20.213 & 1.07 & $\mathrm{C}_{22} \mathrm{H}_{46}$ & Heneicosane,9-methyl- \\
\hline 82 & 20.344 & 0.24 & $\mathrm{C}_{22} \mathrm{H}_{46}$ & Heneicosane,11-methyl- \\
\hline & Total,wt $\%$ & 99.52 & & \\
\hline
\end{tabular}

2.8 The stability of $15 \mathrm{Co5} \mathrm{Ni}-10 \mathrm{Ce}$ in different reaction times

The stability of $15 \mathrm{Co} 5 \mathrm{Ni}-10 \mathrm{Ce} / \gamma-\mathrm{Al}_{2} \mathrm{O}_{3}$ catalyst were performed at reaction temperature with $450^{\circ} \mathrm{C}$, reaction pressure with $2.5 \mathrm{MPa}$, the oil flow rate with $0.1 \mathrm{~mL} / \mathrm{min}$ and the gas flow rate with $30 \mathrm{~mL} / \mathrm{min}$. The used catalysts were calcined at $550^{\circ} \mathrm{C}$ for $6 \mathrm{~h}$ to remove any carbon residue in the muffle stove. Liquid hydrocarbon yields, $\mathrm{H}_{2} \mathrm{O}$ content, oxygenated product content and coke rate were listed in the table 12 . It can be seen from table 12 , the change of oxygenated compound content and coke deposition rate was about 1.5 times. The change of the total content of alkanes and alkenes and the liquid yield was small, which showed that the stability of $15 \mathrm{Co} 5 \mathrm{Ni}-10 \mathrm{Ce}$ catalyst was good.

The FT-IR spectra of liquid products were described and shown in Fig.11. The peak of $1740 \sim 1750 \mathrm{~cm}^{-1}$ almost have no appearance, while the carbonyl absorption peak of $1705 \sim 1720 \mathrm{~cm}^{-1}$ existed and the intensity of the absorption peak was weak in the different times' product, which showed that the decarboxylation and decarbonylation reaction were excellently fulfilled on the fresh and multiple used catalysts. The reason is that the $15 \mathrm{Co} 5 \mathrm{Ni}-10 \mathrm{Ce} / \gamma_{-}$ $\mathrm{Al}_{2} \mathrm{O}_{3}$ catalyst can keep structure stability in this reaction.

Table 12 the analytical result of the conversion of triglyceride to bio-fuels at different times

\begin{tabular}{|c|c|c|c|c|}
\hline & the fresh & the second & the third & the fourth \\
\hline Liquid yield\% & 86.9 & 86.63 & 86.19 & 85.90 \\
\hline Gas yield \% & 11.89 & 12.05 & 12.35 & 12.52 \\
\hline $\mathrm{H}_{2} \mathrm{O} \%$ & 0.063 & 0.068 & 0.073 & 0.083 \\
\hline Coke yield \% & 1.15 & 1.26 & 1.38 & 1.49 \\
\hline Composition of the liquid product & & & & 6.74 \\
\hline aromatics & 5.96 & 6.3 & 6.54 & 43.15 \\
\hline alkanes & 46.51 & 45.86 & 44.66 & 45.58 \\
\hline alkenes & 44.68 & 43.92 & 45.16 & 4.22 \\
\hline oxygenates & 2.64 & 3.16 & 3.45 & 6.46 \\
\hline $\mathrm{C}_{8}-\mathrm{C}_{10} \mathrm{wt} \%$ & 5.23 & 5.82 & 6.79 & 67.18 \\
\hline $\mathrm{C}_{11}{ }^{-\mathrm{C}_{18} \mathrm{wt} \%}$ & 74.92 & 68.85 & 67.23 & 26.05 \\
\hline $\mathrm{C}_{18}{ }^{+} \mathrm{wt} \%$ & 19.64 & 24.57 & 25.79 & 99.69 \\
\hline Total, wt\% & 99.79 & 99.24 & 99.81 & \\
\hline
\end{tabular}

\subsection{The related mechanism and possible equations}

The bond energy of $\mathrm{C}=\mathrm{O}$ is about $736 \sim 749 \mathrm{KJ} \cdot \mathrm{mol}^{-1}$, and the bond energy of $\mathrm{C}$ - $\mathrm{O}$ bond with $360 \mathrm{KJ} \cdot \mathrm{mol}^{-1}$ and the bond energy of $\mathrm{C}-\mathrm{C}$ with 347 $\mathrm{KJ} \cdot \mathrm{mol}^{-1}$, so the reaction of $\mathrm{C}-\mathrm{O}$ and $\mathrm{C}-\mathrm{C}$ bond breaking is more easy at the beginning of the reaction when the reaction temperature increased, and the crude oil easily changed into fatty acid and short chain hydrocarbon fracture.

Vegetable oil can be deoxygenated via three pathways ${ }^{35}$ : decarboxylation, which produces paraffinic hydrocarbon via the removal of the carboxyl group with the release of carbon dioxide; or decarbonylation, which produces olefinic hydrocarbon by the removal of the carboxyl group and the release of carbon monoxide; or hydrodeoxygenation, which produces paraffinic hydrocarbon via the removal the carboxyl group with release of water. When the methanation reaction is negligible, the molar ratio of $\mathrm{CO}_{2} / \mathrm{CO}$ can serve as an indicator for evaluating the reaction pathways of decarboxylation and decarbonylation.
According to the data of GC-MS of the different reaction conditions, the main products were the hydrocarbon compounds under $\mathrm{C}_{18}$, and the minor product was the ketone compounds. Most alkanes and alkenes were hydrocarbons with $\mathrm{C}_{11} \sim \mathrm{C}_{18}$, moreover, odd carbon hydrocarbons with $\mathrm{C}_{13}, \mathrm{C}_{15}$ and $\mathrm{C}_{17}$ were the main compounds. From the results of GC-MS, GC, SF-3 and the FT-IR, we speculated that the first mechanism is one or more fatty acid ester chain $\gamma-\mathrm{H}$ transfer, directly generate less of a carbon atom chain, fatty acid and the unstable intermediate enol. The triglycerides changed into fatty acids and other middle products when the reaction temperature increased, and fatty acids partly became alcohol and small quantity of $\mathrm{H}_{2} \mathrm{O}$ was produced by dehydration of alcohol. The above interpret is agreed with the literature and in particular with the work of Kovács et al. ${ }^{35}$, Katikaneni et al. ${ }^{29}$ and Vonghia E. et al. ${ }^{30}$. The related mechanism and equations are listed below.

Decomposition of the triglycerides and the unstable intermediate enol: 


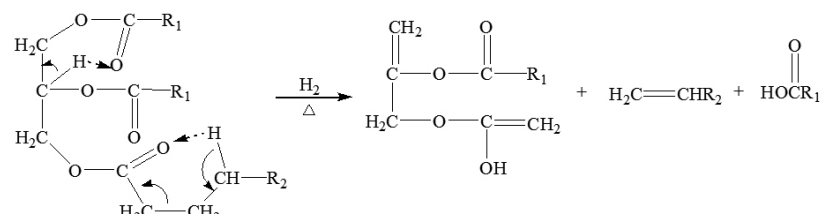

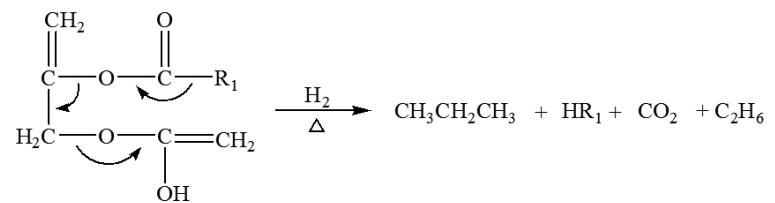

Decomposition and isomerism of the unstable intermediate enol:<smiles>[R][C](O)CCC=C[18OH]</smiles><smiles>[R]C([R4])=O</smiles>
acids:

Decarboxylation $\left(-\mathrm{CO}_{2}\right)$ and decarbonylation $(-\mathrm{CO})$ reaction of fatty

Decarboxylation and decarbonylation reactions of fatty acids generate odd carbon alkenes and alkanes and $\mathrm{CO}$ and $\mathrm{CO}_{2}$ gas. In the $\mathrm{H}_{2}$ condition, odd alkanes and alkenes are the formation of partial olefins by the hydrogenation reaction.

$\|_{\mathrm{O}}^{\mathrm{HO}}-\mathrm{C}-\mathrm{C}_{2 n+1} \mathrm{H}_{4 n+3} \underset{\Delta \text { Cat. }}{\stackrel{\mathrm{H}_{2}}{\longrightarrow}} \mathrm{C}_{2 n+1} \mathrm{H}_{4 n+2}+\mathrm{CO}+\mathrm{H}_{2} \mathrm{O}$

$\prod_{\mathrm{O}}^{\mathrm{HO}} \longrightarrow \mathrm{C}_{2 \mathrm{n}+1} \mathrm{H}_{4 n+3} \underset{\Delta \text { Cat. }}{\stackrel{\mathrm{H}_{2}}{\longrightarrow}} \mathrm{C}_{2 n+1} \mathrm{H}_{4 n+4}+\mathrm{H}_{2} \mathrm{O}+\mathrm{CO}$

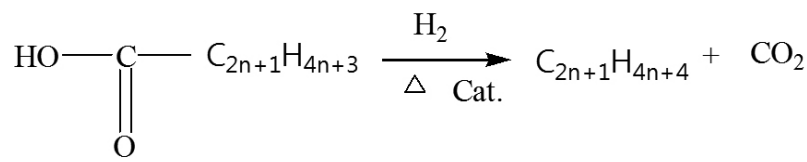

The even carbon alkanes and alkenes are the formation by the hydrogenation and the deoxidization of fatty acids in the $\mathrm{H}_{2}$ condition:

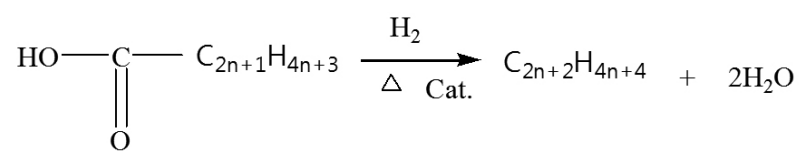<smiles>O=C(O)C=CC=CC=[18O]</smiles>

Splitting decomposition of fatty acids and paraffin:

According to the data of GC-MS, the liquid product contained a small amount of $\mathrm{C}_{8} \sim \mathrm{C}_{11}$ alkanes and aromatic hydrocarbon and alkenes. Because the number of carbon atoms of the fatty acid in the crude oil is mainly made of $\mathrm{C}_{1}$ , $\mathrm{C}_{16}, \mathrm{C}_{18}, \mathrm{C}_{20}$ and $\mathrm{C}_{22}$ carbon atoms, alkanes and aromatic hydrocarbon and alkenes of $\mathrm{C}_{8} \sim \mathrm{C}_{11}$ mostly caused by the common effect of thermal cracking and catalytic cracking.

$$
\mathrm{C}_{2 n} \mathrm{H}_{4 n+2} \underset{\Delta \text { Cat. }}{\stackrel{\mathrm{H}_{2}}{\longrightarrow}} \mathrm{C}_{2 n-2 m} \mathrm{H}_{4 n+2-4 m}+\mathrm{C}_{2 m} \mathrm{H}_{4 m}
$$

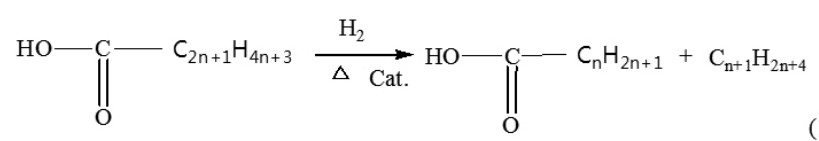

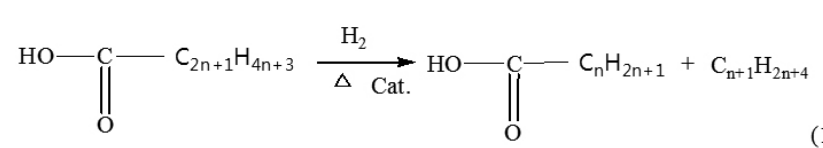

\section{CONCLUSIONS}

The catalysts were prepared and characterized by XRD, BET, $\mathrm{H}_{2}-\mathrm{TPD}$, $\mathrm{NH}_{3}-\mathrm{TPD}$ and TPR analysis, and the $15 \mathrm{Co} 5 \mathrm{Ni}-10 \mathrm{Ce}$ catalyst had good thermal stability and three adsorbed sites and three kinds of acidity sites on the surface. Compared with sintering, the catalyst deactivation was due to coke deposition. The decarboxylation reaction and decarbonylation reaction were excellently fulfilled on the fresh and multiple used catalysts.

The results of FT-IR, SF-3, GC and GC-MS indicated that reaction temperature and oil velocity were very important factors and that reaction pressure was a less important one in producing bio-fuels. The technique was optimized at reaction temperature of $450^{\circ} \mathrm{C}$, reaction pressure of $3.0 \mathrm{MPa}$, oil velocity of $0.1 \mathrm{~mL} / \mathrm{min}$ and the gas velocity of $35 \mathrm{~mL} / \mathrm{min}$. The alkanes content and alkenes content of liquid products are $50.02 \%$ and $40.03 \%$ under the optimized condition. The main products were hydrocarbon compounds under $\mathrm{C}_{18}$.

The results of GC online and trace water determination indicated that the reaction of the decarboxylation and decarbonylation occurred at the same time and the decarboxylation reaction was the main reaction, and the main oxygen in the oil were removed by the forms of $\mathrm{CO}_{2}$ and $\mathrm{CO}$, and the oxygen in the oil was partly removed by the form of $\mathrm{H}_{2} \mathrm{O}$.

From the results of FT-IR, SF-3 and GC-MS, researchers deduce the generating mechanism of Non-ester renewable diesel. The isomerism of the unstable intermediate enol was added to the possible equations about the related mechanism. The research result of continuous conversion of triglyceride to bio-fuels provided a theoretical foundation and scientific basis for solving the problems of energy shortage.

\section{ACKNOWLEDGMENTS}

The authors gratefully acknowledge the financial support of this study by the national natural science foundation China(No.21466021), and the foundation of Educational Department of Jiangxi Province (No.GJJ11276 and No.GJJ11409), and the important foundation of Technological Department of Jiangxi Province (No.20111BBF60028).

\section{REFERENCES}

1. Chheda, J. N.; Huber, G. W.; Dumesic, J. A. Chem. Liquid - phase catalytic processing of biomass-derived oxygenated hydrocarbons to fuels and chemicals. Angew. Chem. Int. Ed. 2007, 46, 7164-7183.

2. Itaya Y.; Kosaka F.; N. Kobayashi. Radiation Properties of Coal Char Particle Cloud, Journal of Chemical Engineering of Japan, 2013, 46, 63 69.

3. Bambang V.; Jae Y.H.; Seok K. K.; Hong S.A.; Young J. K.; Jong S. L.; Shu Y. W.; Oh S. G.; K. Jaehoon. Production of renewable diesel by hydroprocessing of soybean oil: Effect of catalysts, 2012, Fuel, 94, 578585. 
4. Demirbas A. Biofuels securing the planet's future energy needs, Energy Conversion and Management, 2009, 50, 2239-2249.

5. Polycarpou P. Bioethanol production from Asphodelus aestivus, Renewable Energy, 2009, 34, 2525 -2527.

6. Obrecht M.; Denac M. A sustainable energy policy for Slovenia: Considering the potential ofrenewables and investment costs, J. Renewable Sustainable Energy, 2013, 5, 032301-15.

7. Martínez A. A.; Luna J. S.; Hernandez J. G. S.; Hernandez S.; Castro F. I. G.; A. J.C. Montoya. Dehydration of Bioethanol by Hybrid Process Liquid -Liquid Extraction/Extractive Distillation," Industrial \& engineering chemistry research, 2012, 51, 5847-5855.

8. Richard F.; Czernik S. Catalytic pyrolysis of biomass for biofuels production, Fuel Processing Technology, 2010, 91, 25-32.

9. Immer J. G., Kelly M. J.; Lamb H. H. Catalytic reaction pathways in liquid-phase deoxygenation of $\mathrm{C} 18$ free fatty acids, Apply Catalysis A: General, 2010, 375, 134-139.

10. Luo N. J.; Ouyang K.; Cao F.H.; Xiao T.C. Hydrogen generation from liquid reforming of glycerin over Ni-Co bimetallic catalyst, Biomass Bioenergy, 2010, 34, 489-495.

11. Watanabe M.; Iida T.; Inomata H. Decomposition of a long chain saturated fatty acid with some additives in hot compressed water, Energy Conversion and Management, 2006, 47, 3344-3350.

12. James D. Noel; William J. Koros; Benjamin A. McCool; Ronald R. Chance. Membrane-Mediated Delivery of Carbon Dioxide for Consumption by Photoautotrophs: Eliminating Thermal Regeneration in Carbon Capture, Ind. Eng. Chem. Res., 2012, 51, 4673-4681.

13. Sharmila D. N.; Rosfarizan M.; Raha A.R.; Nor'Aini A. R. J. Potential of bioethanol production from Nypa fruticans sap by a newly isolated yeast Lachancea fermentati, Renewable Sustainable Energy, 2012, 4, 0331105.

14. Lim X. Y.; John M. Andrésen. Pyro-catalytic deoxgenated bio-oil from palm oil empty fruit bunch and fronds with boric oxide in a fixed-bed reactor, Fuel Processing Technology, 2011, 92, 1796-1804.

15. Joni P.; Enoch Y. Park. Waste paper sludge as a potential biomass for bio-ethanol production, Korean J. Chem. Eng., 2013, 30(2), 253-261.

16. Balat M.; Balat H. Recent trends in global production and utilization of bio-ethanol fuel, Applied Energy, 2009, 86, 2273-2282.

17. Dai D.; Hu Z.Y.; Pu G.Q.; Li H.; Wang C.T. Chengtao Wang. Energy efficiency and potentials of cassava fuel ethanol in Guangxi region of China, Energy Conversion and Management, 2006, 47, 1686-1699.

18. Sun P.Y.; Sun J.; Yao J.F.; Zhang L.X.; Xu N.P. Continuous production of biodiesel from high acid value oils in microstructured reactor by acidcatalyzed reactions, Chemical engineering journal, 2010,162, 364-370.

19. Li L.X.; Edward C.; Jeffrey R.; Jonathan L. M.; Devin W. Catalytic Hydrothermal Conversion of Triglycerides to Non-ester Bio-fuels, Energy Fuels, 2010, 24, 1305-1315

20. Meher L.C ; Sagar D.V. ; Naik S.N. Technical aspects of biodiesel production by transesterification-a review, Renewable and Sustainable Energy Reviews, 2006,10, 248- 268.

21. Jhuma S.; Kok S. N. Economic and European Union Environmental Sustainability Criteria Assesment of Bio-Oil-Based Biofuel Systems: Refinery Integration Cases, Ind. Eng. Chem. Res., 2011, 50, 6794-6808.

22. Shu Q.;Yang B. L.; Yuan H.; Qing S.; Zhu G. L. Synthesis of biodiesel from soybean oil and methanol catalyzed by zeolite beta modified with $\mathrm{La}^{3+}$, Catalysis Communications, 2007, 8, 2159-2165.

23. Douglas H. S. T.; Houssein K.; Denny K. S. N.; Mahmoud M. E. ; Raymond R. T. Conceptual Synthesis of Gasification-Based Biorefineries Using Thermodynamic Equilibrium Optimization Models, Ind. Eng. Chem. Res., 2011, 50, 10681-10695

24. Marchetti J. M. ; Miguel V. U. ; Errazu A.F. Possible methods for biodiesel production, Renewable and Sustainable Energy Reviews, 2007, 11, 1300-1311.

25. John D. Adjaye; Sai P.R. Katikaneni; Narendra N. Bakhshi. Catalytic conversion of a biofuel to hydrocarbons: effect of mixtures of HZSM5 and silica-alumina catalysts on product distribution, Fuel Processing Technology, 1996, 48, 115-143.

26. Snåre M.; Kubičková I.; Mäki-Arvela P.; Eranen K.; Murzin D.Y. Heterogeneous Catalytic Deoxygenation of Stearic for Production of Biodiesel, Industrial \& engineering chemistry research, 2006, 45, 57085715.

27. Snåre M.; Kubičková I.; Mäki-Arvela P.; Chichova D.; Eranen K.; Murzin D.Y. Catalytic deoxygenation of unsaturated renewable feedstocks for production of diesel fuel hydrocarbons, Fuel, 2008, 87, 933-945.
28. Kubičková I.; Snåre M.; Eranen K.; Mäki-Arvela P. ; Murzin D.Y. Hydrocarbons for diesel fuel via decarboxylation of vegetable oils, Catalysis Today, 2005, 106, 197-200.

29. Katikaneni S. P. R.; Adjaye J. D.; Bakhshi N. N. Performance of aluminophosphate molecular sieve catalysts for the production of hydrocarbons from wood-derived and vegetable oils, Energy Fuels, 1995, 9 (6), 1065-1078.

30. Vonghia E.; Boocock D. G. B.; Konar S. K. Pathways for the deoxygenation of triglycerides to aliphatic hydrocarbons over activated alumina, Energy Fuels, 1995, 9 (6): 1090-1096.

31. Lestari S.; Mäki-Arvela P.; Eranen K.; Beltramini J.; Max Lu G. Q.; Murzin D.Y. Diesel - like Hydrocarbons from Catalytic Deoxygenation of Stearic Acid over Supported Pd Nanoparticle on SBA-15 Catalysts, Catalysis Letter, 2010, 134, 250-257.

32. Simakova I.; Simakova O.; Mäki-Arvela P.; Murzin D.Y. Decarboxylation of fatty acids over Pd supported on mesoporous carbon, Catalysis Today, 2010, 150, 28-31.

33. Do P. T.; Chiappero M.; Lobban L.L.; Resasco D.E. Catalytic Deoxygenation of Methyl - Octanoate and Methyl - Stearate on $\mathrm{Pt} / \mathrm{Al}_{2} \mathrm{O}_{3}$, Catalysis Letter, 2009, 130, 9-18.

34. Şenol O. İ.; Viljava T. R.; Krause A.O.I. Hydrodeoxygenation of methyl esters on sulphided $\mathrm{NiMo} / \gamma-\mathrm{Al}_{2} \mathrm{O}_{3}$ and $\mathrm{CoMo} / \gamma-\mathrm{Al}_{2} \mathrm{O}_{3}$ catalysts, Catalysis Today, 2005, 100, 331-335.

35. Kovács S.; Kasza T.; Thernesz A.; Horváth I. W.; Hancsok J. Fuel production by hydrotreating of triglycerides on $\mathrm{NiMo} / \mathrm{Al}_{2} \mathrm{O}_{3} / \mathrm{F}$ catalyst, Chemical Engineering Journal, 2011, 176-177, 237-243.

36. Nava R.; Pawelec B.; Castaño P.; Álvarez-Galván M.C.; Loricera C.V. ; Fierro J.L.G. Upgrading of bio-liquids on different mesoporous silicasupported CoMo catalysts,Applied Catalysis B: Environmental, 2009, 92, $154-167$

37. Simakova I.; Simakova O.; Mäki-Arvela P.; Simakov A.; Estrada M.; Murzin D.Y. Deoxygenation of palmitic and stearic acid over supported Pd catalysts: Effect of metal dispersion, Applied Catalysis A: General, 2009, 355, 100-108. 